\title{
A narrative inquiry of MTB college athlete's life and career
}

\author{
Jaeyoon Bae ${ }^{1}$ \& Hyunwook Kang ${ }^{2 *}$ \\ ${ }^{1}$ Yonsei University \& ${ }^{2}$ Dankook University
}

\begin{abstract}
[Purpose] The purpose of this study is to look into the life of MTB college athletes before and after their college entrances through long-term longitudinal narrative inquiry and investigate how the career exploration after graduation is conducted in a contextual way. [Methods] For this study, four MTB college athletes who entered the university as specialists are selected as research participants, and their life and career are examined through a long-term longitudinal narrative inquiry. [Results] As a result, the life and career of MTB college athlete appear as follows. First, MTB college athletes entered MTB because of 'self - will' or 'influence of family and acquaintances' and the motivation is 'extension of hobbies', 'college entrance', etc. Second, the MTB college athletes' training and goals are set in the 'college entrance examination', which means the entrance to higher college. Third, MTB college athletes' college life is closely related to 'management and support system for college athletes', and the career search for them is based on 'the prospect as a player' and 'professional prospect of MTB athletes'. However, MTB college athletes showed their plan B to prepare for their uneasy future or to retire. [Conclusions] In the end, the MTB college athletes came to think about life and career on the narrow stage of unpopular sports and was seen coming down from the narrow stage of unpopular sports. Based on these results, this study presents critical discussions about their life and career of MTB college athletes and seeks implications for the school elite sports in Korea.
\end{abstract}

Key words: Mountain bike(MTB), Unpopular sports, School elite sports, Student athlete, College athlete, Career, Narrative inquiry

\section{서 론}

대학생 선수는 '대학에 소속되어 학업과 운동을 병행하 는 학생선수를 말한다(Kang, 2015). 이들은 대학생인 동 시에 운동선수라는 이중 지위를 경험한다(Pflum, Nadler \& Miller, 2017; Raabe, Readdy \& Zakrajsek, 2017). 시기적으로 볼 때, 대학생 선수는 이제 막 성인기에 진입 한 생산인구(age worker)라는 점에서 이들의 진로는 남 다른 의미를 지닌다. 일반적으로 대학생 시기는 한 개인의 장래 직업이 결정되는 중요한 시점이다. 이와 같은 맥락 에서 학생선수의 대학 시기는 대학 이후의 삶을 준비해

논문 투고일 : 2019. 02. 21.

논문 수정일 : 2019. 03. 22 .

게재 확정일 : 2019. 04. 08.

* 교신저자 : 강현욱(leon5989@hanmail.net).
야 하는 과도기적 특성을 지니고 있다. 따라서 대학에 소 속된 학생선수의 삶과 진로를 탐구하는 것은 오늘날 이 들이 마주한 직업시장에 대한 진단이자 미래에 대한 탐색 으로서 의의를 가진다.

그동안 대학생 선수의 삶과 진로를 조명한 연구는 다 음과 같았다. 먼저, '대학생 선수의 삶'과 관련된 선행연구 에서는 대학생 선수의 캠퍼스 생활과 학업에 주목했다 (Han, 2014; Huh \& Shon, 2016; Jang et al., 2013; Jin, 2011; Kang \& Kang, 2012; Kim, 2011; Kim et al., 2017; Kim et al., 2014; Kim et al., 2015; Lee, 2011; Lee \& Ahn, 2014; Lee et al., 2016; Park et al., 2017; Shin, 2010; Yi, 2011; Yim \& Ryu, 2014; Yoon et al., 2011). 대학생 선수는 대학에서 학업과 운 동을 병행해야 하는 다중 역할을 경험해야 하는 위치에서 
캠퍼스 생활에 적응해야 했다. 이에 따라 선행연구에서는 학업과 운동이라는 '두 마리 토끼'를 모두 쫓아야 하는 대 학생 선수의 환경에 대한 논의를 통해 공부하는 학생선 수와 그 제도에 대한 고찰을 시도하였다.

또한, 선행연구에서는 대학생 선수의 운동 및 경기력 향상과 훈련에 관한 연구(Lee, 2015; Park, 2007; Park, 2016; Park \& Shin, 2017; Yoon \& Lee, 2017)를 통해 선수로서의 기량 증진 방안에 대해서도 논의하였다. 대학 생 선수는 대학이라는 고등교육기관에 소속된 만큼 이 기 관에서 제 공하는 운동 프로그램과 훈련에 참여해야 한다. 이에 따라 대학생 선수의 운동 및 경기력 향상이 어떻게 구현될 수 있을지에 대한 구체적인 방안을 모색하는 연구 가 활발하게 진행되었다. 따라서 대학생 선수의 훈련 양 상을 현실적으로 분석한 뒤 개선방안을 제시하는 연구도 다수 수행된 것을 확인할 수 있다.

대학생 선수의 가족 및 주변인(지인, 친구 등), 조력자(감 독, 코치 등)의 존재와 그들의 영향(Cheon et al., 2000; Hwang, Jung, 2014; Lim \& Yim, 2014; Kim \& Hong, 2017; Kim \& Kim, 2015; Lee et al., 2014; Lim \& Yim, 2014)에 주목한 연구도 눈에 띈다. 대학생 선수의 삶을 인적 네트워크(human network)를 기반으로 분석한 연 구에서는 지인의 영향을 분석하였다. 주로 대학생 선수 와 가까운 사람들과의 관계가 선수에게 어떤 영향을 미 치는지를 탐구한 연구가 수행되었다. 이처럼 선행연구에 서는 학생선수의 삶과 관련된 대학 생활과 학업, 운동과 훈련, 인적 네트워크(Human Network)와 그에 따른 영 향 등이 고찰되었다. 이를 통해 대학생 선수의 삶을 들여 다보고 그들의 삶에서 가족 및 주변인의 영향을 살펴보 는 기회를 가졌다.

그리고 '대학생 선수의 진로'와 관련된 선행연구에서 는 대학생 선수의 진로 인식과 그 배경이 되는 실태를 분 석한 연구(An, 2004; Cha, 2012; Kang, 2015; Lee, 2013; Lim et al., 2016; Park, 2013; Son et al., 2014)가 주 를 이맀다. 선행연구에서는 대학생 선수가 자기 진로를 어떻게 인식하는지 분석하고, 이러한 인식이 어떻게 형성 되는지에 대한 고찰이 시도되었다. 그 결과, 오늘날 대학 생 선수의 진로 인식과 진로 인식 형성 과정을 확인할 수 있었다. 아울러 대학생 선수의 사회화에 관한 연구(Choi, 2014; Jang, 2010; Kim \& An, 2017; Lee \& Chung, 2017; Park \& Shin, 2017)에서는 대학생 선수의 적응 과 이탈을 심도 있게 다루었다. 이처럼 대학생 선수의 진
로와 관련된 선행연구에서는 이들의 진로 인식과 실태 를 진단하고, 나아가 학생선수의 사회화뿐만 아니라 중 도 탈락 및 은퇴와 같은 재사회화, 탈사회화에 관한 논의 를 제공하는 데 이바지하였다.

그러나 위 선행연구만으로는 대학생 선수의 삶과 진로 를 입체적으로 이해하는 데 한계가 있다. 대학생 선수의 삶과 진로는 특정 시기에 국한된 것이 아니라 선수생활 전반에 걸친 개인의 역사가 반영되어야 하기 때문이다. 그렇지만 지금까지 수행된 선행연구에서는 대학생 선수 의 삶과 진로를 연구함에 있어 “시간적 연속성을 지닌 한 개인의 삶의 변화와 관련된 연구 주제"나 “연구 참여자의 경험에 대한 맥락”(Lim et al., 2016)에는 소홀한 측면이 있었다. 대학생 선수의 삶과 진로는 이들의 전 생애를 통 해 형성되고 개인의 경험을 토대로 진로가 결정된다는 점 에서 생애사적 내러티브 탐구의 필요성이 제기된다.

본 연구에서는 MTB 대학생 선수 관련 선행연구에서 드러난 한계를 보완하고 나아가 학생선수의 삶과 진로 에 관한 연구의 지평을 확장하고자 'MTB 대학생 선수의 삶과 진로'에 초점을 맞춘 내러티브 탐구(narrative inquiry)를 수행하였다. 지금까지 MTB 대학생 선수의 삶 을 진로와 연계해 고찰한 연구는 부재하였고 이 종목에 서 활동하는 대학생 선수의 내러티브를 탐구한 연구 역 시 시도되지 않았다. 선행연구를 검토한 결과, MTB와 관 련된 선행연구는 주로 여가몰입 (Han, 2017; Kim, 2015) 에 관한 것이었으며, MTB를 경험한 대학생을 대상으로 한 연구(Park \& Kang, 2017)는 있었으나 이마저도 학 생선수를 대상으로 한 연구는 아니었다. 그러므로 MTB 대학생 선수의 삶과 진로에 관한 내러티브 탐구는 선행 연구의 한계를 극복하는 새로운 연구로서 의미를 가질 것이다.

한국에서 MTB(Mountain bike, 이하 MTB)는 산악 자전거라는 이름으로 명명되는 익스트림스포츠(Extreme Sports)를 말한다. MTB가 익스트림스포츠로 분류되는 것은 자전거를 타고 산악지대나 비포장도로를 달리기 때 문이다. 일반적으로 MTB 종목에는 크리스컨트리(Crosscountry), 다운힐(Down hill), 듀얼 슬라롬(Dual slalom), 힐 클라이밍 (Hill climbing), 4-Cross, 구간 경기 등이 있 는데 모두 고난도의 기술이 요구된다. 이에 따라 MTB는 고도의 전문성과 숙련성을 바탕으로 즐기는 스포츠로 유 명하다. 익스트림스포츠의 화려함 이면에 가리어진 MTB 학생선수의 삶은 대회 출전을 위한 고된 훈련의 연속이 
다. 여기서 눈에 띄는 것은 다른 종목과 비교할 때 MTB 학생선수의 삶에 대한 주목도가 낮다는 점이다. 이는 인 기스포츠와 비인기스포츠의 차이가 학생선수의 세계에 서도 여과 없이 적용되는 것을 방증한다. 또한, 대중은 이 들의 진로가 어떤 방식으로 설계되고 전개되는지에 대해 서도 무관심했다. 그 결과, 야구, 농구, 축구 등 인기종목 의 학생선수들이 받는 관심에 비해 MTB 학생선수의 이 야기는 상대적으로 주목도가 낮았다.

지금까지 MTB 학생선수의 삶과 진로는 '그들만의 리 그' 안에서도 “섬 문화”(Yu \& Yi, 2004)를 형성하는 독특 한 양상으로 전개되었다. 이 같은 배경에서 MTB 대학생 선수의 삶과 진로는 나름의 고유한 영역을 구축하고 있을 것으로 짐작된다. 그러므로 본 연구에서는 아직 잘 알려 지지 않은 MTB 대학생 선수의 삶과 진로를 그들의 이야 기인 내러티브를 통해 가감 없이 살펴보고자 한다. 구체 적으로 이들이 $\mathrm{MTB}$ 에 입문하게 된 배경과 동기는 무엇 인지, 학생선수로서 훈련과 목표는 무엇인지, 그리고 대 학생 생활과 향후 진로에 대한 탐색은 어떻게 이루어지고 있는지 등을 중심으로 MTB 대학생 선수의 삶과 진로를 탐구하고자 하였다. 다시 말해 본 연구에서는 MTB 대학 생 선수의 대학 입학 전후의 삶을 총체적으로 들여다보 고, 대학 졸업 이후에 관한 진로 탐색이 맥락적으로 어떻 게 이루어지는지를 살펴보고자 하였다.

\section{연구방법}

\section{연구의 인식론적 근거}

본 연구에서는 MTB 대학생 선수의 삶과 진로를 총 체적으로 고찰하고 맥락적으로 이해하기 위하여 내러 티브 탐구(narrative inquiry) 방법을 활용하였다. 내러 티브 탐구는 Clandinin \& Connelly가 교사 연구를 수행 하며 개발 및 발전시킨 연구 방법이다(Yeom, 2003). 존 듀이 (John Dewey)의 "경험에 근거한 존재론적, 인식론 적 가정”(Kim \& Lee, 2017)까지 거슬러 올라가는 철학 적 배경을 가진 내러티브 탐구는 자신 또는 타인의 경험 에 내재한 의미를 확인하기 위해 시간의 연속성을 기반으 로 탐구하는 연구 방법을 말한다. Clandinin \& Connelly (2000)는 삶의 경험을 이야기하고 다시 이야기하는 과 정을 통해 경험의 의미를 끊임없이 재구성하고, 일련의
사건을 단편적으로 나열하는 데 그치는 것이 아니라 시간 의 흐름에 따라 구조화하며 해석하는 것을 내러티브 탐 구로 보았다.

본 연구에서는 내러티브 탐구를 활용하여 MTB 대학 생 선수의 대학 입학 전후의 삶을 총체적으로 들여다보 고 졸업 후 진로에 대한 탐색이 어떻게 맥락적으로 이루 어지는지 살펴보고자 하였다. MTB 대학생 선수의 내러 티브는 개인의 수많은 이야기가 유의미하게 연결되어 있 다는 점에서 연속성 있는 이야기로 구성된다. 또한, 총체 적 삶의 의미 차원에서 MTB 대학생 선수의 내러티브는 이야기의 맥락을 확인할 수 있게 해준다. 따라서 MTB 대 학생 선수를 대상으로 이들의 이야기를 연속성 있게 해 석 및 재해석하기 위해서는 내러티브 탐구가 가장 적절 한 연구방법일 것이다. "인간은 개인적으로 사회적으로 이야기되는 삶을 살아가는 이야기하는 유기체"(Clandinin \& Connelly, 2000)이므로 내러티브 탐구 방법을 활용해 MTB 대학생 선수의 삶과 진로를 살펴보고자 한 것이다. 즉, 본 연구에서는 MTB 대학생 선수의 삶을 이야기하고 다시 이야기하는 과정을 통해 경험의 의미를 재구성하고, 시간의 흐름에 따라 이들의 경험이 어떻게 맥락화되는지 를 살펴보는 데 초점을 맞추었다.

Clandinin \& Connelly(1991)에 따르면, '내러티브'란 긴 시간에 걸쳐 있는 삶에 대한 사건들을 뜻한다(Yeom, 2003). 내러티브는 구조를 지닌 이야기이며 이야기들이 모여 하나의 종합적인 이야기를 만들어낸다(Kim, 2016; $\operatorname{Kim} \&$ Lee, 2017). 그러므로 내러티브 탐구는 시간적 연 속성이 있는 사건 즉, 여러 이야기를 유기적으로 연관 지 어 살펴보는 것이다. 이에 대해 $\operatorname{Lim}(2008)$ 은 "개별적 행 위와 사건들은 단순히 묘사하는 것이 아니라 그 관계들을 연결하여 유의미하게 연속되는 이야기를 구성함으로써 무질서와 혼동의 형태로 존재하는 과거의 경험에 의미를 부여"하는 것으로 보았다.

따라서 내러티브 탐구는 단일한 상황에 대한 단편적인 해석에 머무는 것이 아니라, 이야기로 구성된 인간의 경 험을 해석 및 재해석하는 방법으로 볼 수 있다. Kim \& Lee(2017)는 내러티브가 "플롯 형식을 지니고 있기 때문 에 해석이 따른다"고 보았다. 다시 말해, 연구자의 해석에 따라 사건이 배열되고 플롯이 구성된다는 것이다. 결국,

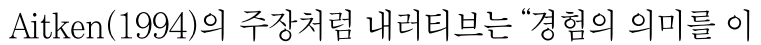
끌어내기 위한 효과적 방법” 중 하나로써 연구자가 연구 참여자 개인의 삶을 종합적으로 조명하는 데 있어 탁월한 
연구 방법인 것이다. 이에 따라 본 연구에서는 Clandinin \& Connelly(2000)의 내러티브 탐구에 방법론적 토대를 두고, $\operatorname{Kim}(2013)$ 이 제시한 내러티브 탐구의 절차에 따 라 연구를 수행하였다.

\section{연구 참여자 선정}

내러티브 탐구에서 연구자와 연구 참여자의 관계는 매 우 중요하다. 그 이유는 연구자와 연구 참여자가 서로 “똑 같은 영감(spirit)"(Clandinin \& Connelly, 2000)을 갖 고 탐구하기 때문이다. 이에 대해 Kim \& Lee(2017)는 연 구자와 연구 참여자가 "존중하고 서로 배우며 변화에 참 여하는 존재"로 보았다. 그러므로 연구자는 내러티브 탐 구의 특성을 고려해 긴밀하게 협조가 가능한 참여자를 섭 외하고자 노력하였다. 이를 위해 전국에 있는 MTB 대학 생 선수 중 다음 세 가지 요건을 충족하는 자를 연구 참여 자로 선정하였다.

첫째, 특기자 전형으로 대학에 입학한 MTB 학생선수 이다. 특기자 전형으로 대학에 입학했다는 것은 대학 입 학 이전부터 MTB 종목에서 활약한 것을 의미한다. 본 연 구에서는 특기자 전형으로 대학에 입학한 학생선수여야 더욱 풍부한 내러티브를 갖고 있을 것으로 보고 이를 연 구 참여자 선정의 기준으로 삼았다. 둘째, 대학의 MTB팀 (산악자전거부)에 소속된 학생선수이다. 본 연구에서는 MTB 학생선수의 내러티브를 보다 심층적으로 탐구하기 위하여 대학 MTB팀에 소속된 학생선수를 섭외하고자 하였다. 셋째, MTB 대학생 선수로서 자기만의 내러티브 를 갖고 있다고 생각하며, 그 내러티브가 종목의 특수성 에 의한 것으로 볼 수 있는 선수다. 연구자는 단순한 자기 내러티브를 넘어 MTB 학생선수로서의 삶과 진로에 대해 고민을 하는 자를 연구 참여자로 선정하고자 하였다. 위
와 같은 기준에 따라 적합한 대상을 추려낸 뒤 연구의 주제 와 목적을 설명하고 연구 참여에 대한 의사를 확인하 였다. 그 결과, 연구자와 유기적인 소통 및 긴밀한 협력 이 가능할 것으로 판단한 총 4 명의 MTB 대학생 선수를 연구 참여자로 선정하였다. 연구 참여자의 개인적 특성은 〈Table 1〉과 같았다.

본 연구에 참여한 MTB 대학생 선수들은 자발적으로 연구에 참여하였다. 연구자는 연구 참여자가 갖고 있을 거부감과 불안을 경감하기 위하여 면담 관련 내용을 사 전에 조율하였다. 그리고 연구 참여자와 최초 면담 앞서 자발적인 참가임을 재확인하였다. 연구자는 면담에 앞 서 연구 참여자의 권리와 의무를 설명하고 '연구 참여 동 의서'에 서명을 받았다. 연구 참여 동의서에는 연구자의 성명, 소속, 연락처를 명시하였다. 연구 참여 동의서는 같 은 내용으로 제작해 연구자와 연구 참여자가 서명 후 각 자 보관할 수 있도록 하였다. 그리고 면담 후 요구되는 연 구 참여자의 역할(연구 참여자 검토, member checking) 에 대해서도 자세히 설명하였다. 이러한 과정을 통해 연 구의 윤리성을 확보하였다. 면담 내용의 녹음은 연구 참 여자가 사전 동의하는 경우에만 실시하였다. 면담의 녹음 파일과 전사지는 연구자와 연구자가 지정한 자만이 청취 및 열람할 수 있도록 하였고, 그 과정에서 연구 참여자의 개인정보가 노출되지 않도록 유의하였다(Bae, 2017).

\section{내러티브 탐구의 절차 및 수행}

내러티브 탐구의 대표적인 방법은 Clandinin \& Connelly (2000)의 절차이다. Clandinin \& Connelly(2000)의 내 러티브 탐구는 다섯 단계의 과정으로 구성되어 있다. 그 절차는 '현장에 존재하기', '현장 텍스트로 이동하기', '현 장 텍스트 구성하기', '경험에 대한 의미 구성', '연구 텍스

Table 1. Personal characteristics of the participants

\begin{tabular}{ccccccc}
\hline \hline No & Name & Gender & $\begin{array}{c}\text { Age } \\
\text { (Birth Year) }\end{array}$ & MTB field & Year of MTB Athlete registration & Year of college admission \\
\hline 1 & Minwoo Kang & Male & $20(1997)$ & Cross-country & 2011 (9th grade) & 2016 \\
\hline 2 & Bumsoo Choi & Male & $23(1994)$ & Cross-country & 2012 (12th grade) & 2013 \\
\hline 3 & Sungmin Han & Male & $22(1993)$ & Cross-country & 2011 (12th grade) & 2012 \\
\hline 4 & Hyoil Kim & Male & $23(1994)$ & Cross-country & 2011 (11th grade) & 2013 \\
\hline \hline
\end{tabular}

Participants' names are pseudonyms. 
트 구성'으로 이루어진다. 그러나 본 연구에서는 내러티 브 탐구의 기존 절차를 재구성한 $\operatorname{Kim}(2013)$ 의 탐구 과 정이 본 연구의 목적을 더욱 명확히 드러낼 것이라는 판 단으로 $\mathrm{Kim}$ (2013)이 제시한 절차를 적용하였다. $\mathrm{Kim}$ (2013)이 제시한 내러티브 탐구 절차는 모두 여섯 단계 로 구성되어 있으며, 이 절차를 적용한 본 연구의 세부적 인 절차는 다음과 같았다.

첫 번째는 '연구주제와 연구목적 확립하기' 단계이다. 연구자는 MTB 대학생 선수의 삶과 진로에 관련된 선행 연구를 분석하고 관련 이론을 검토하였다. 선행연구들 은 주로 학생선수의 삶과 이들의 진로를 고찰한 연구들 이었다. 그리고 선행연구의 지적배경이 된 이론은 한국스 포츠의 엘리트선수 육성제도와 학생선수 육성방식이었 다. 연구자는 선행연구와 관련 이론을 검토한 뒤, 비인기 종목에서 활동 중인 대학생 선수의 삶과 진로를 조명한 연구가 부재한 것을 확인하고 연구의 필요성을 인식하였 다. 그 후, 본 연구의 주제와 목적을 MTB 대학생 선수의 삶과 진로에 대한 내러티브 탐구로 확립하였다.

두 번째는 '연구 주제에 적합한 연구 참여자 선정하기' 단계이다. 연구자는 대학에 소속된 MTB 학생선수의 학 업 현장과 운동 및 훈련 장소, 대회 현장 등을 고려해 현 장 경험이 풍부한 자를 연구 참여자로 선정하고자 하였 다. 또한, MTB 학생선수의 다양한 삶과 진로에 대해 살 펴보기 위하여 선수로서 자신만의 주관과 가치가 뚜렷한 자를 연구 참여자로 선정하고자 노력하였다. 내러티브 탐 구의 특성상 연구자와 연구 참여자의 협력이 매우 중요한 점을 고려해 연구 참여자 후보군을 추려낸 다음 몇 가지 기준에 따라 연구 참여자를 선정하였다. 그 기준은 특기 자 전형 입학생, 대학 팀 소속 여부, 자기 내러티브에 대 한 분명한 인식 등이었다. 그 외에 자신의 삶과 진로를 왜 곡 없이 묘사할 수 있는 자를 추려내어 연구 참여자 4 명 을 선정하였다.

세 번째는 ‘현장 자료 다양하게 수집하기’ 단계이다. 연 구자가 수집한 현장 자료는 심층 면담과 전사 자료, 비 참여 관찰, 현장노트, 연구 참여자의 활동이 기록된 자료 등이었다. 연구자는 4 명의 연구 참여자로부터 심층 면담 의 자료가 포화를 이룰 때까지 일대일 (1:1) 개별 면담을 진행하였다. 심층 면담은 2017년 3월 15일부터 4월 30 일까지 진행되었고 연구 참여자별로 2 3차례에 걸쳐 실 시하였다. 심층 면담에 소요된 평균 시간은 90 분에서 110 분가량이었으며 반구조화된 면담으로 진행하였다. 심층
면담의 주요 질문은 "MTB에 입문하게 된 배경과 동기에 대해 말해주세요.", “학생선수로서 훈련과 목표는 무엇입 니까?", "대학 생활은 어떠하며 졸업 후 진로는 어떻게 계 획하고 있나요?”와 같았다. 그 결과, 방대한 분량의 전사 자료가 생성되었고 이를 통해 연구 참여자의 이야기를 재 구성할 수 있었다. 가공되지 않은 자료는 전사 자료뿐 만 아니라 비참여 관찰과 현장 노트도 있었다. 연구자는 MTB 대학생 선수들이 소속된 대학의 운동 및 훈련 환경 (대학의 MTB부 전용 공간, 실내 트레이닝 장소, 대학 인 근에 있는 야외 훈련장 등)과 대회 현장(2017년에 개최 된 한국산악자전거연맹 경기 대회)을 관찰하였으며, 이 때 연구자가 느낀 생각과 감정을 반성하며 기록한 현장 노트 역시 자료로 활용하였다. 마지막으로 연구 참여자가 직접 기록한 활동 소감과 $\mathrm{SNS}$ 기록 역시 현장 자료로써 수집하였다.

네 번째는 '자료를 주제별로 묶고 범주화하기' 단계이 다. "이 단계에서는 수집된 다양한 자료들을 연구자가 분 석하게 된다. 연구자는 수집된 현장 텍스트를 기술하는 과정을 거치는데, 동시에 연구자는 기술된 현장 텍스트 를 계속해서 읽고 쓰는 과정에서 드러나는 공통적인 주 제나 패턴, 경험 등을 추려내서 범주화해야 한다" (Kim, 2013). 본 연구에서는 내러티브 분석 (narrative analysis) 또는 내러티브 방식의 분석 (narrative mode of analysis)을 사용하였다. 이 방법은 “보편적이지 않은 상황 에서 발생하는 인간 행 동의 특별한 성격에 주목” (Kim, 2017)하는 것으로 연구 참여자의 내러티브를 해석하는 데 도움을 준다 (Kim, 2016). MTB 대학생 선수를 대상 으로 수집한 자료를 분석한 결과, 이들의 삶과 진로에는 몇 가지 공통적인 주제로 묶을 수 있는 패턴과 경험이 발 견되었다. 이를 영역별로 범주화하여 연구 결과에 반영 하였다. 이 과정에서 연구자는 MTB 대학생 선수의 이야 기를 듣고 다시 이야기하기 위해 현장 텍스트를 기술하는 과정을 거쳤으며, 그 과정이 엄밀하게 진행될 수 있도록 반복적으로 읽고 쓰며 분석하였다.

다섯 번째는 '연구자의 경험적·사회적 의미 부여하기' 단계이다. 연구자들은 MTB 학생선수 출신이 아니었다. 그렇지만 연구 참여자의 이야기를 듣고 재구성하면서 지 속적인 의미 재형성의 시간을 가졌다. MTB 대학생 선수 인 연구 참여자들은 그들의 삶과 진로에 대해 진지하게 이야기하였다. 특히, 대학이 이들에게 주는 의미와 MTB 선수로서 살아가기에 대한 개인적 의미는 이 연구의 목적 
과 방향성을 뚜렷하게 해주는 내용들이었다. 연구자는 이 들의 이야기를 토대로 다시 이야기하고 의미를 재형성하 기 위하여 MTB 대학생 선수의 개인적 경험들을 연대기 별로 재구성해 의미 추적을 시도하였다. 그 후, 연구 텍스 트로 정리한 자료에 사회적 맥락을 대입하고 타인과의 관 계성을 유추하여 연구의 정당성 (justification)을 확보하 였다. 이렇게 정리한 자료는 연구 참여자에게 검토 $\left(\mathrm{mem}^{-}\right.$ ber checking)를 의뢰하여 과장이나 축소처럼 왜곡된 부 분은 없는지 점검하였다.

여섯 번째는 '연구 텍스트 구성하기' 단계이다. 연구자 는 연구 참여자의 목소리를 중심으로 연구 텍스트를 작 성하고자 하였다. 이를 위해 삼차원적인 탐구 공간(시간 적 차원, 공간적 차원, 개인적·사회적 차원) 속에서 발생 하는 연구 참여자의 삶과 진로를 입체적으로 보여주는 데 집중하였다 (Connelly \& Clandinin, 2000). 본 연구는 참 여자의 삶과 진로에 초점을 맞춰 개인 중심의 내러티브 를 탐구한 만큼 연구자보다 연구 참여자의 언어로 연구 텍스트를 구성하였다. 즉, 연구 텍스트 구성에 있어 연구 참여자의 비중을 고려한 것이다. 나아가 MTB 대학생 선 수가 경험한 삶과 진로를 복합적인 삶의 양상으로 풀어 냈으며 이들의 내러티브를 시간, 장소, 사회·문화적 맥락 속에서 해석하였다.

\section{신뢰성과 일관성}

“내러티브 탐구의 이야기는 개인적인 이야기다. 학문적 인 구조 속에서 연구가 진행된다고 하지만 과연 연구자 가 진실을 이야기하고 있는지에 대한 의문이 들기 마련이 다. 따라서 그 개인적 이야기의 특성 때문에 과학적인가 또는 개인적이지 않은가라는 질문에 항상 휩싸이게 된다" (Kim, 2013). Polkinghorne(1988)과 Huberman(1995) 은 내러티브 탐구의 신뢰성과 일관성의 수단을 따로 마 련해야 한다고 주장하였다. 본 연구에서는 신뢰성과 일관 성을 확보하기 위하여 이들의 주장(접근성, 정직성, 현실 성, 실제성, 친밀성, 전환 가능성, 경제성)을 반복 비교, 지속 검토, 멤버 체크, 동료 검증을 시행하였고, 연구 참 여자의 이야기 자료와 연구자의 해석이 구분될 수 있도록 연구 텍스트를 기술하였다. 또한, 결과 부분에 연구 참여 자의 인용문을 제시함으로써 독자에게 "연구자의 해석의 기초가 된 자료들” $(\mathrm{Kim}, 2013)$ 을 직접 확인할 수 있도록 하였다. 그리고 연구자가 자신의 해석에 함몰되지 않도록
연구 참여자와 정보 제공자의 비판적 검토를 수용 및 참 고하였다. 이를 통해 연구의 신뢰성을 높이고 해석의 일 관성을 도모하였다.

\section{결 과}

본 장에서는 MTB 대학생 선수의 삶과 진로를 그들 의 목소리를 통해 재현하였으며 연구자의 시선으로 재 구성하였다. 그 결과, 네 명의 MTB 대학생 선수의 삶과 진로는 다음과 같이 재현 및 전개되었다.

\section{강민우의 이야기}

유년기의 스포츠 참여 경험은 성인기 여가 스포츠 활 동의 밑거름이 된다. Hong(2002)은 유년기 스포츠 리 그 참가가 미래 여가활동에 상당한 영향을 미치며 향후 여가태도 발달에도 중요한 요인으로 작용한다고 지적하 였다. 즉, 어린 시절 경험한 스포츠는 성인이 된 후에도 영 향을 미친다는 것인데(Bae \& Choi, 2016), 연구 참여자 강민우의 개인적 경험 역시 이와 일맥상통한다. 강민우 는 어린 시절부터 자전거를 좋아했다. 그는 다섯 살 때부 터 두발자전거를 타기 시작했는데 훗날 그 경험은 MTB 선수가 되는 밑거름이 된 것으로 판단된다. 평소 자전거 를 좋아했던 강민우는 유튜브(YouTube)로 MTB를 처 음 접하게 된다.

자전거를 워낙 좋아해서 동영상을 많이 찾아봤는데 사이클 을 타는 동영상보다 산악자전거[MTB]를 타는 동영상이 확 와닿는 느낌이 있었어요. 그래서 주로 산악자전거 동영상만, 자연스럽게 그쪽MTB]으로 끌리게 된 거 같아요. (Kang, 22 세, MTB 대학생 선수)

MTB는 산지나 험로를 무대로 하기에 호불호가 나뉘 는 종목이다. 게다가 잘 포장된 도로나 트랙을 달리는 것 이 아닌 험준한 지형에서 즐겨야 하는 익스트림스포츠 $\left(\mathrm{ex}^{-}\right.$ treme sports)인만큼 그에 대한 선호도는 극명하게 나뉜 다. 이 같은 특성으로 말미암아 MTB는 마니아(mania)의 참여도가 월등히 높은 종목으로 알려져 있다(HuybersWithers \& Livingston, 2010; Ham et al., 2016). 강민 우는 동영상으로 본 MTB에 매료되었다. 그러나 자전거 에 대한 관심은 교육열이 높은 지역에서 자란 성장환경 탓에 내적 갈등을 유발하는 원인이 되기도 하였다. 
강남구 대치동에서 자란 강민우는 교육열로 유명한 환 경적 영향으로 내적 갈등을 겪게 된다. 이는 학업에 전념 하는 또래들과 다른 진로를 모색하는 데에서 기인한 것이 었다. 당시 중학교 2학년이었던 강민우는 평범한 또래들 과 다른 길을 가는 것에 불안감 (Kim, 2011; Lee, 2011) 이 컸던 것으로 회상했다. 중학생 시기에 또래 집단의 여느 학생들과 다른 진로를 선택하는 것은 결코 쉬운 일 이 아니기 때문이다(Coakley \& Pike, 2009).

제가 운동선수를 계속하고 싶었는데 부모님한테 운동선수를 하고 싶다고 선뜻 말하기가 좀.., 음.., 곤란했어요. 왜냐하면, 제 주변 $\cdots$. 대치동 주변에 정말 내놓으라 하는, 공부만 하는 친구들밖에 없었고 운동이라면 모험적인 면이 없지 않아 있 으니깐 저도 그걸 알기에 [부모님께 MTB 학생선수가 되겠다 고] 선뜻 말하기 어려웠어요. (Kang, 22세, MIB 대학생 선수)

강민우의 고민은 교육열이 유난히 높은 강남 8학군의 배경과 밀접한 연관이 있다. 그는 MTB 선수라는 진로 선 택에 대한 부모의 반응이 부정적일 것으로 예상했기에 쉽 게 말하지 못했다. 그런데도 그는 부모에게 자신이 희망 하는 진로에 대해 털어놓았다. 중학교 2학년이 끝나갈 무 렵(12월), 처음으로 부모에게 MTB 선수가 되고 싶다고 이야기한 것이다. 그 계기가 된 것이 바로 친한 친구의 사 례였다. 이 시기, 그의 친구가 볼링선수를 준비하겠다고 한 것에 자극받은 것이었다. 친한 친구로부터 '용기'를 얻 은 강민우는 부모에게 MTB 선수가 되고 싶다는 의사를 피력하고 이에 지원을 요청하게 된다.

저랑 친한 친구 중의 한 명이 갑자기 볼링선수를 한다고 부 모님한테 말했다고 들어서 저도 그거에 좀 용기를 얻어서 “나 지금 요즘 눈여겨보고 있는 운동이 있는데 지금 그 운동 을 하고 싶다"라고 말씀드렸어요. $\cdots$ [중략] $\cdots$ [다음 해] 3월 에 첫 시합에 나갔는데 입상을 해서 부모님도 '잘 하는구나!' 생각하셨는지 그때부터는 전폭적으로 지원해 주셨어요. (Kang, 22세, MTB 대학생 선수)

이듬해 강민우는 아산 충무공이순신배 전국산악자전 거대회의 중등부에서 입상하면서 본격적으로 MTB 학생 선수의 길을 걷게 되었다. 강민우는 자전거에 대한 관심 이 MTB로 이어져 학생선수의 길을 걷게 된 사례였다. 그 는 학생선수에 대한 개인적인 편견(학생선수에 대한 부 정적인 시각)과 상황적 환경(교육열이 높은 지역에서 자 란 배경과 가정환경)을 극복하면서 부모의 지지를 얻어 냈다. 흔히 학생선수에게 있어 조력자의 존재는 필수적이
다(Coakley \& Pike, 2009). 그런 점에서 강민우는 MTB에 대한 열정을 입증해 부모의 지지를 얻은 주체적 사례로 볼 수 있을 것이다.

\section{"MTB로 갈 수 있는 최고의 대학을 목표로"}

여느 학생선수들과 마찬가지로 MTB 학생선수의 삶은 훈련의 연속이었다. 이들은 학생선수로서 자신이 세운 목 표를 달성하기 위해 매일 자전거에 올랐다. MTB 학생 선수의 삶은 주로 '대회에서 성적을 내기 위해 쉼 없이 훈 련하는 과정'으로 요약된다. 이들은 MTB를 더 잘 타기 위 해 기초 체력부터 기술훈련까지 끊임없이 자신을 단련해 야만 한다. 이들이 이렇게 열심인 이유는 이러한 과정을 견뎌내야만 MTB 학생선수로서 경쟁력을 확보할 수 있 기 때문이다. 중학교 3학년 때부터 학생선수 생활을 시작 한 강민우는 처음 출전한 대회에서 입상했다. 우수한 성 적으로 중등부 순위권에 든 것이다. 강민우는 첫 대회 출 전을 위해 3 개월 동안 준비했다. 중학생이었던 그는 개인 코치로부터 지도받으며 방과 후 4 시간가량 $100 \mathrm{~km}$ 씩 달 리며 훈련했다.

한강 따라서 나가다 보면 남산하고 북악스카이웨이라고 있 어요. 남산도 고불고불 올라가는 길이 있고 북악산으로 해서

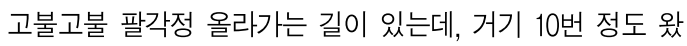
다 갔다. 올라갔다, 내려갔다, 올라갔다, 내려갔다. (Kang, 22 세, MTB 대학생 선수)

고등학생이 된 강민우는 훈련에 매진했다. 그러나 그 는 학생선수로서 온전히 운동만 할 수 있는 여건은 아니 었던 것으로 회상하였다. 강민우의 부모는 MTB를 타는 것에 동의했지만, 그의 결정을 일종의 '모험'처럼 여겼다. 그래서 그의 부모는 운동 외 다른 진로에 대해서도 고려 할 수 있도록 최소한의 여지를 남겨 두고자 했다. 그 결 과, 부모의 설득으로 인문계 고등학교에 진학한 강민우는 학업과 운동을 병행해야만 했다. 이로 인해 강민우는 인 문계 고등학교로 진학하였고, 학외 활동으로 MTB를 타 야 했다.

부모님이 제가 외동이라서 그런지 몰라도 그때까지도 좀 고 민을 많이 하셨나 봐요. 아무래도 체육고등학교를 가면 그쪽 에 국한되어 있으니깐 "네가 진짜 하고 싶으면 인문계 고등 학교에 가서 학교 끝나는 시간에 맞춰서 그때부터 운동해라" 그래서 어쩔 수 없이 집 근처 인문계 고등학교에 갔죠. [중략] 중학생 때는 일찍 끝나니깐 저녁에 운동할 시간이 충분했는 
데 고등학생 때는 7교시, 8교시까지 기본적으로 있으니깐 화 요일, 목요일 이렇게. 월, 수, 금은 정상 수업하고 화요일, 목 요일은 조퇴하는 식으로 운동을 했죠. (Kang, 22세, MTB 대 학생 선수)

주말은 제일 운동하기 좋은 날이죠. 그래서 외곽으로 나가 죠. 자전거 타고 미사리 이렇게 해서 남양주 가서 유명산 쪽 으로 가서 저쪽으로 타던가 아니면 내려와서 경기도 광주 쪽, 팔당 쪽으로 타던가 그런 식으로 장거리훈련을 했죠. 주 말 중 하루는 150-180km 정도 (Kang, 22세, MTB 대학생 선수)

강민우의 목표는 MTB를 열심히 타서 '좋은 대학에 진 학하는 것'이었다. 그는 체육특기자로 대학에 입학하기 위해 고등학생 시절을 MTB와 함께 보냈고 여러 대회에 출전해 입상하였다. 그러나 꾸준한 노력에도 불구하고 부 상으로 인해 어려움을 겪기도 했다. 스포츠 선수에게 있 어 부상은 가장 견디기 힘든 일이다. 부상은 스포츠 선수 의 활동을 제약하고 경력을 단절시키는 주된 원인이기 때 문이다(Kim \& Kwon, 2013; Park et al., 2016). 특히, 입 시를 앞둔 고교 학생선수에게 부상이 주는 심리적 중압 감은 상대적으로 더 크기에 부상회복에도 악영향을 미친 다(Han et al., 2009). 강민우 역시 잦은 부상에 시달렸 으며 부상으로 인한 심리적 압박에 늘 노출되었던 것으로 나타났다. 그는 부상을 안고 훈련하면서도 대학 진학에 대한 꿈을 포기하지 않았던 것으로 확인되었다. 또한, 대 학 진학을 위해 실업팀의 영입 제안을 거절할 만큼 대학 진학에 대한 강한 의지를 갖고 있었다.

저도 실업팀에 갔으면 3천만 원 정도 받았을 건데 $\cdots$. 저는 일단 대학팀에 가고 싶었기 때문에 실업팀 제안을 거절하고 대학에 왔죠. 다른 친구는 자전거만 집중해서 타고 싶다고 해서 실업팀에 갔고. [중략 여기가 MTB로 올 수 있는 최고 의 대학이니깐. (Kang, 22세, MTB 대학생 선수)

\section{“불안한 미래와 플랜 B"}

요즘은 거의 훈련을 잘 안 하고요, 그냥 수업에서 학점을 챙 기려고 노력하고 있어요. (Kang, 22세, MTB 대학생 선수)

강민우는 MTB 대학생 선수의 생활이 만족스럽지 않 다고 하였다. 자신이 원해서 대학팀에 진학했지만 학생 선수를 위한 대학의 지원도 충분치 않았고 체계적인 관 리도 이루어지지 않았기 때문이다. 대학 입학 전에는 이 런 상황에 대해 잘 몰랐기에 합격한다는 것만으로도 기
뺐으나 입학 후 대학팀의 열악한 현실을 경험하고 학생 선수 생활에 회의를 느끼게 되었다고 말했다. 그는 MTB 로 대학에 왔지만 대학은 그가 기대했던 것만큼 선수생 활에 최적화된 곳이 아니었다.

강민우가 진학한 대학에서는 MTB 학생선수를 특기자 전형으로 선발하되 이들을 위한 학생선수 프로그램은 운 영하지 않았다. 그의 대학에서는 체육특기자를 선발해 체 육학과에 배정한 후 자유롭게 운동할 수 있도록 유도하 고 있었다. 이로 인해 강민우처럼 보다 체계적인 관리를 기대했던 학생선수들은 대학팀에 실망할 수밖에 없었다. 그가 진학한 대학팀에는 전담 코치나 트레이너 등 전문 지도자가 없었고 학생선수들을 위한 훈련 프로그램도 운 영하고 있지 않았다. 이에 따라 대학팀에 소속되어 있지 만 훈련은 자율적으로 해야 했고 학생 선수끼리 일정을 맞춰 함께 훈련하는 환경에서 MTB를 타야 했다.

이외에도 MTB 학생선수들에게 있어 군 복무는 선수 경력 단절로 이어질 수 있기에 이 시기에 대한 고민이 많 은 것으로 드러났다. 특히, 국군체육부대(상무)처럼 입대 후에도 자신의 종목에서 운동할 기회가 마련되어 있다면 다행이나 대부분의 MTB 대학생 선수는 그런 기회를 얻 기 힘든 상황이었다. 실제로 국군체육부대에서는 MTB 선 수보다 사이클 선수를 더 선호하기에 MTB를 타며 군 복 무를 하는 경우는 흔치 않았다. 그 결과, MTB 학생선수 대부분은 자신의 특기인 MTB와 무관한 곳에서 국방의 의무를 수행하고 있는 것으로 나타났다. 군 복무 기간 동 안 단절된 선수 경력은 대학팀 활동에 지장을 주는 핵심 요소로 지목되었다.

안 그래도 없는 동기를 더 떨어트리는 요소 중 하나가 군대, 올해 가야 해서 뭐... 지금부터 운동을 열심히 하더라도 1년 9 개월 갔다 와버리면 완전히 몸이 다운되는 거니깐, 그걸 알 기 때문에 더 운동할 욕구가 안 생기기죠. [중랙 이게 심폐 지구력 거의 뭐.. 자전거대회에서의 $80,90 \%$ 는 심폐지구력, 심폐근지구력. 이 부분이다 보니깐 이제 1년 9개월 갔다 오 면은 아마 눈에 보여요. 얼마나 기량이 하락했을지 보이니 깐. 군대에 자전거를 가져갈 수도 없는 노릇이고... (Kang, 22세, MTB 대학생 선수)

강민우는 MTB 학생선수로서 불만족스러운 대학의 팀 운영 행태와 군 복무로 인한 경력단절 등에 대한 부담이 향후 진로선택에 영향을 미치고 있는 것으로 이야기하 였다. 그리고 MTB 학생선수를 하면서 얻게 된 부상의 후 유증을 고려할 때 대학 졸업 후에도 MTB 선수를 지속할 
수 있을지에 대해 불안해하는 모습을 보였다. 학생선수의 탈사회화, 재사회화에 관한 이슈는 늘 존재해왔다. 이는 MTB 대학생 선수에게도 예외는 아니었다. 특히, 종목의 특성상 대중성이 낮은 비인기 종목의 학생선수들은 미래 에 대해 더 큰 불안감을 갖고 있기 마련이다. 문제는 이들 의 불안이 일상적으로 지속되고 있다는 것이다. 강민우 역시 비인기 종목에서 운동하는 MTB 학생선수로서 자신 의 미래를 준비하기 위해 운동이 아닌 다른 분야로 진로 를 탐색하는 모습을 보였다.

지금 생각은 플랜 B도 항상 고려를 해두고 있어요. [중략] 전 공 살려서 체육 쪽으로 나갈 생각도 있고, 제가 유치원부터 중2 때까지 항상 원하던 그런 장래희망이 있었는데, 그게 파 일럿(Pilot)이었는데 비행기 조종사. 그것도 보고 있고. 조금 동떨어진 거 같지만 찾아보니깐 조종사의 수요도 부족하고 그쪽도 일반 4년제를 졸업하고 갈 수 있는 길이 많다고 해서 그것도 좀 알아보고 있고. 아버지는 사업, 제가 외동이다 보 니깐 아버지 사업도 한번 생각해보면 안 되겠냐는 말씀도 하 셔서 이렇게 크게 세 가지... (Kang, 22세, MTB 대학생 선수)

이처럼 강민우는 MTB 선수의 길로 계속 갈 수 없다면 다른 분야로 진로를 전환할 것을 염두에 두고 있었다. 자 기 분야에서 직업적 안정성이 보장되지 않은 만큼 파일럿 (pilot)이나 가족 사업을 대안으로 고려 중이었다. 결국, 강민우가 고려하는 '플랜 B'는 오늘날 비인기 종목의 대학 생 선수들이 경험하는 선수로서의 불안한 미래와 관련 있 다. 아울러 MTB 선수로 닮고 싶은 롤 모델(role model) 이 없다는 것도 강민우가 '플랜 B'를 마련해야 하는 원인 으로 작용하였다.

지금 MTB로 제일 잘된 선배라고 하면 사이클아카데미 차려 서 그 학원을 운영하는 선배인데, 그 선배도 딱히 $\cdots$. 그 선배 도 정말 힘들게 학원을 운영하세요. 노인분들 가르치고, 어 린 애들 가르치고, 학생도 가르치고. 그렇게 살아서 그다지 우상이 될 만한 선배는 거의 없어요. (Kang, 22세, MTB 대학 생 선수)

\section{최범수의 이야기}

저희 아버지가 일이 좀 안 좋았어요. 쌍용 다니시는데 그때 한창 안 좋을 때 있었잖아요? 그때 아버지가 스트레스 푸신 다고 타셨거든요. 그러다 다른 자전거를 하나 더 사신 거예 요. 두 개가 된 거예요. 아빠가 [남는 MTB를] 타보래서 탔죠. (Choi, 25세, MTB 대학생 선수)
최범수는 아버지의 추천으로 MTB를 처음 타게 되었다. 의미 있는 타자(significant others)의 영향으로 MTB를 시작한 것이다. 최범수는 고등학교 1학년이 되던 시기인 2010년 3월경에 MTB를 처음 접했는데 이는 아버지의 취미가 아들의 취미로 이어진 것이다. 그는 아버지의 영 향으로 MTB를 알게 되었고, 같은 동네에 살던 지인에 의 해 재능을 발견하게 되었다.

동네에 MTB 국가대표 형이 있었어요. 어쩌다가 같이 타게 됐어요. 그 형이 저에게 "잘 탄다, 잘 탄다" 해주니깐, 아빠가 "OO(이)도 좀 타봐라" 해서 입문하게 되었어요. (Choi, 25세, MTB 대학생 선수)

최범수는 MTB를 취미로 즐겨왔다. 그러다 자신의 재 능을 눈여겨본 동네 형의 추천으로 MTB 동호회에 가입 하게 되었고, 이후 정기적으로 라이딩 (riding)을 하면서 대회에도 출전하게 되었다. 2011년 영주에서 개최된 전 국대회에 출전한 최범수는 비록 입상에는 실패했지만, 여 기서 자신을 이끌어줄 지도자를 만날 수 있었다. 취미로 시작한 MTB가 진지한 여가(Stebbins, 1982)로 이어지 면서 대회에 출전하게 되고 그곳에서 자신의 재능을 알아 본 코치를 통해 학생선수의 길로 들어서게 된 것이다. 학생선수의 길을 걷게 된 최범수는 평일에는 수업이 끝난 뒤 훈련을 했고 주말에는 장거리 훈련으로 대회를 준비 하였다.

학교에서도 야자[아간자율학습] 다하고 훈련해야 하니깐. 근 데 야자까지는 뺐는데 빼고도 5 시에 끝나잖아요, 보통 학교 가. 밤에 나가서 계속 타고. 그렇게 하고 주말에 시간 비니깐 그때 장거리훈련 많이 나가고. 코치님하고 같이 하고 그런 식으로 준비했죠. 많은 양은 아니었는데 그 짧은 시간에 집 중하게 되니깐 뭔가 효율이 있었던 거 같아요. (Choi, 25세, MTB 대학생 선수)

MTB 학생선수는 한국산악자전거연 맹에 선수 등록을 해야 입시 때 대회 기록을 인증 받을 수 있다. 최범수의 경 우, 고등학교 1 2학년에는 선수등록을 하지 않고 대회 에 참가했지만, 경력 인증 체계를 뒤늦게 인지하고 고등 학교 3학년이 되어서야 정식으로 선수등록을 하게 된다. 최범수의 목표 역시 대학 진학이었고 연맹에 선수로 등록 한 이후에는 대회에서 입상해야 했기에 훈련에 더 집중하 였다. 그러던 중 대회 성적이 꾸준히 좋게 나오자 실업팀 에서 최범수에게 관심을 보였다. 이를 계기로 최범수는 
한때 대학이 아닌 실업팀 진출도 고려했었던 것으로 이야 기하였다. 그러나 실업팀 관계자들이 주목한 전국체전대 회에서 입상하지 못하면서 최범수의 목표는 대학 진학에 만 전념하는 것으로 바뀌었다.

원래 대학이 목적이었거든요, 근데 몸이 신기하잖아요. 너무 잘 올라오는 거예요, 잘 발전하고. 그래서 체전, 솔직히 체전 전까지는 대학만 생각했거든요. 저는 경기도에서 있었으니 깐 경기도 대표로 나갔는데 거기서도 합숙을 해요, 체전 전 에. 의정부시청이랑 같이 훈련했거든요, 가평군청이랑. 의정 부시청에서 저한테 관심이 있더라고요. 메달 따면 데려간다 고 하니깐 그때 갑자기 마음이 바뀐 거예요, '아, 정말 [실업 팀] 가면 좋겠다.' 대학만 생각하고 실업팀 생각은 안 했어요, 애초에. 저는 갈 수 없을 줄 알고. [중략 체전도 처음 나가고 엄청 큰 대회잖아요, 한국에서. 너무 긴장되는 거예요. 탔는 데 첫 바퀴 때 엉겨 넘어진 거예요, 대구 선수들이랑. 그때 말려서 $\cdots$ (Choi, 25세, MTB 대학생 선수)

\section{"운동과 학업, 두 마리 토끼를 쫓는 것에 대한 부 담감"}

운동도 많이 배울 수 있고, 제 운동에 집중할 수 있게 해 줄 수 있을 줄 알았어요. (Choi, 25세, MTB 대학생 선수)

대학에 입학한 최범수는 MTB 대학생 선수가 되었다. 대회도 고등부가 아닌 대학부로 출전하게 된 것이다. 대 학을 '중간 목표'로 삼고 MTB를 탔던 최범수는 자신의 꿈 을 부분적으로 이루었다. 그는 대학에 진학하면 과학적이 고 체계적인 훈련과 코칭 시스템이 마련돼 있을 것으로 기대했다. 하지만 대학 MTB부의 현실은 그의 기대에 부 응하지 않았다.

최범수는 대학 진학 후 운동에만 전념할 수 있을 것으 로 기대했다. 대학에서 운동만 할 수 있도록 여건을 마련 해 줄 것으로 기대한 것이었다. 그러나 MTB부에 소속된 학생선수 역시 다른 학생들과 마찬가지로 수업을 들어 야 했고 졸업 조건을 갖추지 못하면 졸업할 수 없었다. 흔히 말하는 체육특기자에 대한 특혜가 존재하지 않았 던 것이다. 체육전공 내 다른 학생들과 똑같이 공부해야 했고 졸업을 위한 요건도 갖추어야 했다. 자전거만 타면 될 것이라는 최범수의 기대와 달리 MTB 대학생 선수는 운동과 학업, 두 마리 토끼를 모두 쫓아야했다.

00 대랑 $\mathrm{OO}$ 대는 아예 도로[사이클]선수도 있고 트랙 선수도 있어서 코치를 두고 전문적으로 [운동]하는데 저희[우리 학
교]는 저희[학생선수들]끼리 [자체적으로 운동]해야 되잖아 요. 그것 때문에 뭔가 다른 거 같아요. [중략 수업도 일반 학 생이랑 똑같이 들어야 되고. [중략 그렇다 보니 '여건이 그렇 게 좋지는 않구나', '운동에 집중할 수 없겠구나'라고 생각했 어요. (Choi, 25세, MTB 대학생 선수)

[시합과 수업이 겹쳐서] F학점 받은 게 한 두 개가 아니었어 요. 공문을 내도 교양에서는 택도 없어요. [교수님이] 이해를 안 해주세요. 아무리 공문 내도 안 된다는 사램교수도 있어 요. 만약에 시합이 토요일, 일요일인데 먼저 가 있어야 되잖 아요. 공문에는 토, 일만 표시되어 있으니깐 결석 사유가 안 되는 거죠. 유도리 없게... [중략] 체전 때 합숙훈련을 해요. 그 합숙 기간이 학기 중인 건데 그것도 인정 안 해주는 교양 도... 그때 그것도 $\mathrm{F}$ 맞고. 그건 진짜 공문 제대로 났는데. (Choi, 25세, MTB 대학생 선수)

체육특기자로 대학에 진학한 최범수는 MTB만 열심히 타면 졸업할 수 있을 것으로 생각했다. 하지만 학생선발 은 체 육특기자로 이루어졌지만, 대학 생활은 체육과의 여 느 학생들과 마찬가지로 해야 하는 상황이었다. 즉, 최범 수는 운동과 학업을 병행해야 하는 MTB 학생선수의 특 수한 환경에 실망한 것이다. 이러한 불만은 고교생 시절 자신과 라이벌이었던 친구의 실업팀 활약상을 지켜보며 더 커졌다.

저랑 똑같이 탔던 애였는데 경쟁하고 제가 이길 때도 있고. 개는 실업팀 가서 돈 받고 타는데 저는 대학 와서 아무것도 안 받고 부모님 돈 쓰면서 훈련하고 하는데 그냥 그렇더라고 요. 이게 진짜 비등한데 개는 돈 받고 타고 저는 여기서 제대 로 못 하고 있고. 열심히 타도 쫓아갈 수 있을까도 의문인데 공부도 해야 하니 또 막 스트레스를 받더라고요. (Choi, 25세, MTB 대학생 선수)

그는 대학에서 운동만 하는 것이 아니라 학업도 병행 해야 하는 것을 '시간 낭비'로 느꼈다. 운동에만 전념하고 싶었던 최범수에게 학업을 병행해야 하는 것은 부담이었 기에 스트레스였다. 최범수는 MTB 학생선수의 상황을 경 험하면서 운동과 학업을 동시에 해야 하는 대학 생활에 만 족할 수 없었다. 그렇다고 그가 당장 실업팀으로 옮길 만 큼 실력이 출중하거나 경력이 화려한 것도 아니었던 만큼 $\mathrm{MTB}$ 학생선수의 삶을 받아들여야 했다. 그렇지만 MTB 학생선수로서 대학 생활을 하는 것이 녹록치 않고 불만인 것은 변함없는 사실이었다. 그는 선수로서 더 성장하고픈 열망이 있었지만, 체계적인 선수 관리 프로그램이 부재한 것과 학업을 병행해야 하는 학생선수 학사제도를 문제로 여겼다. 
저도 욕심은 크죠. 선수로서 더 성공하고 싶은데. 저도 운동 만 하면 잘 할 수 있어요. 제가 말씀드렸듯이 대학이 항상 걸 림돌인 거 같아요. 아빠한테도 말했어요. "이럴 거면 대학 안 갔으면..." 그리고 아빠 회사에서도 그게 있대요. 자기 나가 면은 자식 들어올 수 있는 그런 제도도 있대요. 근데 대학생 들이 잘 없잖아요, 생산직에. 오히려 더 전문적으로 배운 애 들, 고졸 애들. 차라리 대학을 안 갔으면 더 운동은 취미로 하다가 그쪽으로 빠져도 되는 건데 지금은 안 되는 거잖아 요. 지금은 이도 저도 아닌 거잖아요. (Choi, 25세, MTB 대학 생 선수)

최범수는 MTB 선수로서 경쟁력을 강화하기보다 자 전거 지도자의 진로를 모색하고 있었다. 자신을 잘 아는 코치가 $\mathrm{BMX}$ 강사직을 소개해 준 것을 계기로 자전거 지 도자의 길을 경험하고 있었다. 최범수는 MTB 선수 생활 을 계속하지 못할 경우에 대비해 같은 영역 내 다른 진로 를 모색하고 있는 것이었다. BMX라는 종목이 자신의 주 종목은 아니었지만, 미래에 대한 준비와 투자의 차원에서 $\mathrm{BMX}$ 강사 일을 하는 것으로 설명했다. 그에게 $\mathrm{BMX}$ 지 도자는 MTB 선수의 대안이었다.

$\mathrm{BMX}$ 라고 좀 작은 자전거 있어요. 제 종목은 아닌데 같은 자 전거고 하니깐. 저희 사이클연맹에서 유소년사업 하고 있거 든요. [중략 강사도 메리트[merit]있다고 생각한 게 지금부터 해두면 강사도 급수가 있잖아요. 지금 3급인데 점점 애네도 급수가 있거든요, 선수들도. 지도자들도 같이 올라가요, 경력 이 쌓이면서. 2급, 1 급 이렇게 올라가면서 애들 성장하잖아 요. 만약에 올림픽 됐어요. 국가대표 코치라도 뽑혀야 되잖ㅎㅎㅎ 아요, 누군가 돼야 되잖아요. 그럼 저도 이런 거 지금부터 하 면은 나중에 비전이 있죠. (Choi, 25세, MTB 대학생 선수)

\section{한승민의 이야기}

한승민이 MTB를 시작하게 된 것은 삼촌의 영향이었 다. 자전거매장을 운영하는 삼촌의 소개로 MTB를 알게 된 것이다. 산에서도 자전거를 탈 수 있다는 걸 알게 된 한승민은 6학년 때부터 MTB를 타기 시작했다. 처음에는 아버지의 자전거를 타다가 중학생이 된 이후에는 삼촌의 가게에서 남은 부품으로 조립한 자신만의 MTB를 갖게 된다. 어린 시절 그는 집 주변 등산로에서 MTB를 탔는데, 이는 자신의 유일한 취미이자 놀이거리였다.

삼촌이 매장에 “놀러 한 번 와봐라" 해서 아버지랑 같이 놀 러 갔는데, 삼촌이 서울에 있는 뒷산에 데려가더니 "이렇게
타는 거다"고 보여주셨어요. 그걸 보고 "아! 이거 재미있겠구 나!' 했어요. 삼촌이 옆에서 같이 타고 저도 따라 탄 거예요. (Han, 26세, MTB 대학생 선수)

한승민이 MTB에 입문한 배경에는 삼촌이 큰 역할을 했던 것으로 보인다. 삼촌은 그에게 MTB를 처음 소개했 고 타는 법도 알려주었다. 한승민은 자신의 삼촌을 통해 $\mathrm{MTB}$ 를 알게 되었고 입문하게 된 것이다. 한승민은 자신 의 삼촌이 MTB를 시작하고 즐길 수 있게끔 하는 데 가장 큰 영향을 준 사람이라고 평가했다. 결국, 한승민이 MTB 에 입문하게 된 배경과 동기에는 가족인 삼촌이 있었고, 지금까지 MTB를 계속 타는 것도 삼촌의 영향이 크게 작 용하고 있는 것으로 밝혔다.

\section{“취미를 살려 대학 가기"}

한승민이 MTB를 탄 것은 취미였기 때문이다. MTB로 대학에 진학할 수 있다는 걸 몰랐던 한승민은 고등학교 2 학년 때까지 선수등록을 하지 않은 채 온전히 취미로만 즐 겼다. 그래서 고등학교 2 학년 때까지 전문적인 훈련을 해 야 할 필요성을 느끼지 못했던 것으로 보인다. 한승민은 $\mathrm{MTB}$ 를 취미로 즐겨왔기 때문에 자전거를 잘 타기 위한 체 계적인 훈련을 해야 할 이유가 없었던 것이다. 그는 MTB 에 처음 오른 초등학교 6학년 때부터 고등학교 2학년 때 까지 여가로 MTB를 즐겨왔다. 따라서 한승민에게 MTB 는 수단이 아니라 그 자체가 목적이었다. MTB를 즐겁게 타는 것이 목적이었던 한승민은 같은 취미를 즐겼던 아 버지의 조언이 유일한 지침서였다.

[MTB를] 재미 삼아 남는 시간에 타고, 시합에 나갔다 오면 ‘뭐 가 부족하다' 그런 것들을 저희 아버지가 말씀해 주셨어요. 저는 그게 부족하다고 생각을 못 했었거든요. '오르막길이 부족 하다' 그러면 오르막길 연습을 하고, 아버지가 "이번 시합은 코스가 이렇대" 하면 아버지 말 듣고 비슷한 코스를 찾아서 가 서 연습하고 그런 식으로 한 거죠. 따로 훈련 계획서에 따라 이렇게 한 건 없어요. (Han, 26세, MTB 대학생 선수)

한승민에게 삼촌과 아버지는 취미생활의 동반자였다. 이들은 취미로만 MTB를 즐겼던 한승민에게 훈련의 필요 성을 강조하기도 했고 자전거를 계속 탈 수 있도록 독려 하기도 했다. 고등학교 1학년 때 한승민은 한동안 자전거 를 멀리했다. 양평에서 개최된 ' $280 \mathrm{~km}$ 랠리 (Rally)'에 무 리하게 참가한 후유증 때문이었다. 한승민은 중학생 때부 터 그 대회를 동경했었지만, 어려서 참가할 수 없다는 아 
버지의 만류로 대회에 출전할 수 없었다. 그러다 고등학생 이 된 이후, 아버지와 함께 대회에 참가했지만 코스를 힘 겹게 완주한 한승민은 한동안 자전거에 질려버린 것으로 기억했다. 이로 인해 대회 후 약 3개월 정도 자전거를 타 지 않고 지냈다. 한승민은 이 시기를 극복할 수 있었던 것 도 삼촌과 아버지의 영향이라고 이야기했다. 비록 취미로 자전거를 타고 있었지만, 삼촌과 아버지는 그가 자전거에 소홀한 모습을 싫어했다고 한다. 그래서 그의 삼촌과 아 버지는 한승민에게 새로운 동기를 부여하고자 훈련을 권 했던 것으로 보인다.

아버지가 저한테 말씀해 주셨는데 "너는 조금만 훈련하면 등 수 안에 들 수 있는데 왜 안 하나?”고 말씀하셨죠. "아버지 말씀이 맞는 거 같은데 다시 해볼까?' 다시 고등학교 시합에 나갔는데 그게 아마 고1 때 무주대회 시합이었을 거예요. 그 때는 좀 훈련을 되게 많이 하고 나갔고 저희 작은아버지가 저한테 순위 안에 들면 선물 하나 줄게. 자전거 프레임 바꿔 준다고 말씀하신 거예요. 이를 악물고 해서 그때 처음으로 등수에 들었을 거예요. (Han, 26세, MTB 대학생 선수)

한승민은 취미로 MTB에 올랐지만 중학교 때부터 고 등학교 때까지, 중등부와 고등부 시합에 꾸준히 출전할 만 큼 열정적이었다. 함께 취미 생활을 즐겼던 삼촌과 아버 지의 영향도 있었지만 한승민 스스로가 MTB를 좋아했다. 자신이 좋아하는 취미를 가족의 지지를 바탕으로 즐기는 것은 매우 중요하다. 가족의 관심은 학생선수 활동에 있 어 큰 힘이 되기 때문이다(Coakley \& Pike, 2009). 삼촌 과 아버지와 함께 MTB를 즐겼던 한승민은 고등학교 3학 년이 되어서야 한국산악자전거연맹의 MTB 학생선수 등 록 제도를 알게 된다. 이전까지 한승민은 대회 참가 선수 였지 연맹에 등록된 학생선수가 아니었다. 이 때문에 그 의 기록은 학생선수로서 관리되지 않았고 경력 또한 입 시에 활용할 수 없었다. 이를 눈여겨보던 삼촌이 그에게 선수등록을 권하면서 고등학교 3학년에 들어서야 한국산 악자전거연맹의 학생선수로 정식 등록하게 되었다.

고등학교 2학년 때 한 번 연맹시합을 나갔었는데 그게 가평 에서 하는 시합이었거든요. 거기서 제가 연맹시합에서 고등학 교팀 중에서 2등을 했어요. 4월에 있던 시합이었는데 시합 나 가고 고3 돼서 삼촌이 저한테 말씀해 주셨어요. "너 선수등록 을 해야 대학교에 갈 수 있다" 그때 안 거죠. 선수등록 해야 된 다. 저는 '아 그냥 내가 갖고 있는 상장만 내면은 이게 인증이 되는구나.'라고 알았는데, 연맹에서 주는 기록지를 내야지 인 정이 되는 거더라고요. '아, 그러면 어차피 고등학교 2학년 때
시합했던 거 하나 있으니깐 하면 되겠다.' 했는데 이게 선수 등록을 안 한 상태에서 기록이 저장이 안 된다고 해가지고 '아 그럼 망했다. 큰일 났구나'! (Han, 26세, MTB 대학생 선수)

MTB 학생선수는 체육특기자로 대학에 진학할 수 있다. 그러나 한승민은 체육특기자 전형에 요구되는 선수등록 절차에 대해 모르고 있었다. 고등학교 2학년 때부터 순 위권 입상이 잦아지면서 그의 재능을 눈여겨본 삼촌에 도 움으로 연맹 선수로 등록할 수 있었다. 이때부터 한승민 은 자신의 취미가 대학 진학에 영향을 미칠 수 있다는 것 을 인식하고 대학 진학에 요구되는 경력을 만들어가기 시작했다.

\section{“평범한 학생선수의 삶과 동호인으로 회귀"}

MTB 학생선수가 되어 MTB를 탄다는 것은 한승민에 게 꿈이었다. 대학 입학으로 그 꿈을 이룬 한승민은 대학 생활에 대한 기대가 컸다. 체계적인 훈련과 코치진의 지 도로 MTB를 더 잘 탈 수 있을 것으로 기대한 것이다. 그 러나 한승민의 기대와 달리 대학 MTB부는 학생선수들이 자체적으로 운영하고 있었다. 동아리처럼 운영되던 MTB 부는 매년 100 여만 원의 재정 지원과 지도 교수의 지정 정 도로 명맥을 유지하고 있었다. 코치진이 부재한 가운데 신 입생 시절 한승민은 단 한 차례의 대회도 출전하지 않았다.

감독이나 코치 밑에서 운동을 배우는? '아, 자전거 되게 잘 타 지겠구나.' 처음 배워보니깐 그런 기대감이 있었죠. '잘 타게 되겠구나.' 했었는데, [대학에] 오니깐 '아니네, 내가 생각했던 그런 대학교가 아니구나, 일반 학생들처럼 똑같이 수업 듣고 성적 매기고 그렇게 하는 거구나.' 그때 좀 그랬죠 '아, 내가 생 각했던 데가 아니구나.' [중략 대학교 딱 들어와서 3월 중순, MT 갔다 와서부터 '그냥 일반 학생들처럼 지내는 곳이구나. 내 가 운동할 수 있는 곳은 아니구나.' 그때 알았죠. (Han, 26세, MTB 대학생 선수)

한승민은 대학 입학 후 MTB부의 운영에 실망했다. 대 학에 MTB부는 학생선수들을 중심으로 자율적으로 운영 되고 있었고 단체 훈련의 강제성도 없었다. 그리고 함께 입학한 MTB 동기들도 운동에 소홀해 부서에 잘 나타나 지 않았다. MTB부 선배들 역시 적극적으로 후배들을 이 끌어주지 않았던 탓에 한승민은 혼자 공부하고 틈틈이 자 전거를 탔다고 한다. 그러다 입대를 앞둔 2학년 1학기에 는 단 한 번도 MTB를 타지 않았던 것으로 드러났다. 대 학에서 훈련해야 할 필요성을 느끼지 못했으며 동기 부여 도 전혀 되지 않았기 때문이다. 
1 학년 때는 저 혼자 계속 개인 운동하면서 그때도 그냥 선수 등록 안 했으니깐 협회 시합만 꾸준히 나가고. 그러고 있다 가 대학교 2학년 1학기에 마치고 2학기 때 군대에 갔거든요. 대학교 2학년 때는 제가 어차피 군대에 갈 건데 선수등록을 해서 뭐하냐, 1 년 동안 10 만 원 내고 하는 건데 선수등록 해 봤자 뭐하냐 군대 갈건데 하지 말자. 대학교 2학년 때는 또 자전거를 안 탔죠. 2학년 1학기 때부터 자전거를 안 탔어요. (Han, 26세, MTB 대학생 선수)

한승민에 의하면 그는 “평범하게 대학 생활을 한 것”이 었다. MTB 학생선수로 입학했지만, 자전거를 타지 않은 것이다. 신입생이었던 1 학년과 군대 가기 전이었던 2 학 년 1학기를 그렇게 보낸 뒤, 제대 후 자신을 이끌어주는 MTB부 선배를 만나 다시 훈련하게 되었다. 그렇게 2학 년 2학기를 보내고 3학년 때는 선수등록을 한 뒤 MTB 를 탔다. 그러나 대학생 선수들이 자체적으로 훈련을 하 다 보니 기량이 크게 늘지 않는 한계가 있었고 자연스레 훈련에 대한 열정도 기복이 심했다. 한승민은 3학년 2학 기에 접어들어서는 친한 선배의 졸업과 가깝게 지내던 후 배의 입대로 훈련에 대한 열기가 식었던 것으로 기억했 다. 이러한 과정을 거쳐 4학년 1학기까지 MTB 학생선수 로 생활을 한 것이다. 이제 졸업을 한 학기 남겨둔 상황에 서 한승민은 자전거매장을 운영하는 쪽에 관심을 갖고 있 었다.

생각해보니깐 여태까지 제가 한 건 자전거밖에 없으니깐 그 쪽 분야를 살리려고 하거든요. 그래서 저번에 말씀드린 것처 럼 저희 작은아버지[삼촌]가 서울에서 매장을 운영하시는데 그 매장에서 일을 배울 거예요. 서울에서 일을 좀 배우고, 경 영도 삼촌이 하시는 거 보면서 배우다가 나중에 내 매장을 차 리는 게 어떨까 그런 생각을 하고 있거든요. (Han, 26세, MTB 대학생 선수)

현재 한승민은 MTB 선수로서 자신의 생명은 끝난 것 으로 자평했다. 실업팀에 진출하기 위해서는 꾸준한 대회 출전과 입상 경력이 있어야 하는데 자신은 그렇게까지 준 비를 안 했다는 것이다. 한승민은 삼촌이 운영하는 자전 거매장에서 일을 배우고 자신의 가게를 여는 것이 앞으로 의 계획이라고 밝혔다. MTB는 취미로 즐기되 선수 생활 은 대학생 때까지만 하겠다는 것이다.

자전거를 그만두는 건 아니고 그 대신 그냥 취미로만 계속 타 는 거죠. [자전거] 매장 운영하면서 매장에 오는 사람들하고 친해지기 위해서, 친목. 경영이죠. 친해지면서 같이 운동하고
그나마 거기서 내가 알고 있는 거는 그 사람보다 더 많이 탔 으니깐 좀 알려줄 수 있고 그렇게 해서 하는 거죠. [중략] 동 호인이 되는 거죠, 쉽게 예기하면. (Han, 26세, MTB 대학생 선수)

한승민은 MTB 대학생 선수를 끝으로 다시 동호인으 로 돌아가려 했다. 고등학교 3학년 때부터 선수등록을 한 한승민의 선수 기간은 길지 않았다. 약 4년간의 MTB 대 학생 선수 생활을 마치고 다시 동호인으로 회귀하고자 하 는 것이었다. 그런 까닭에 그는 선수 생활을 그만두는 것 에 대한 아쉬움도 크지 않았다. 오히려 MTB를 부담 없이 탈 수 있다는 점에서 동호인 생활이 그리웠던 것으로 말 하였다. 학생선수 생활을 끝으로 동호인 세계로 돌아가려 는 한승민의 모습에서 MTB 대학생 선수의 중압감과 부 담감을 확인할 수 있었다.

\section{김효일의 이야기}

\section{"MTB는 대학 진학을 위한 전략적 선택"}

김효일은 대학 진학을 위해 MTB에 올랐다. 김효일이 $\mathrm{MTB}$ 에 입문한 것은 대학 진학을 염두에 둔 전략적 선택 이었다. 그는 체육특기자로 대학에 들어가고자 MTB를 시작한 것이었다. 따라서 김효일에게 MTB는 대학 진학 의 도구로 활용되었다. 정리하면, 김효일이 MTB에 오르 게 된 데에는 대학 진학이라는 뚜렷한 목적이 있었고, 이 종목을 통해 대학에 입학하고자 한 그의 전략적 선택이 구체적인 동기가 되었던 것으로 해석된다. 그러므로 김효 일의 MTB 입문은 다른 연구 참여자들과는 달리 인위적 인 측면이 강했던 것으로 보인다.

고1 때 정한 거죠. 고1 말에. 고1 때까지 공부를 하다가 대학 이 좀 힘들 거 같아서 뒤늦게 '운동 시작해보자' 해서 '무슨 운동을 할끼?' 이때부터 찾은 거죠. 고1 때. [중략] MTB를 하 려고 운동을 시작한 게 아니라, '운동해야겠다.' 정해놓고 무 슨 운동을 할까 찾다가 MTB를 탄 거죠. (Kim, 25세, MTB 대 학생 선수)

고등학교 1학년 말부터 $\mathrm{MTB}$ 를 시작한 김효일은 체육 특기자로 대학에 진학하기 위하여 MTB를 선택하였다. 그 는 원래 MTB가 아닌 사이클 (cycling) 종목을 선택하려 했 으나 '시작이 너무 늦어 경쟁력이 없다'라는 판단이 들어 선수층이 얇은 MTB로 종목을 바꾼 것이다. 실제로 김효일 이 대학 진학에 유리한 스포츠 종목을 고민하던 2010년 
경에는 연맹 대회에 출전하는 고등부 선수가 7 9명밖에 없었다. 그는 이러한 현황을 파악하고 사이클보다 MTB 를 타는 것이 더 유리할 것으로 판단한 것이다.

원래 처음에는 사이클을 하려고 했었어요. 아버지 권유로 사 이클을 해보려 했는데 너무 늦은 거죠. 사이클은 중학교 때 부터 차근차근히 하던 애들이라서 제가 중간에 그렇게 할 수 가 없어서 사이클 할 바에는 좀 더 비인기인 산악자전거를 해보는 게 어떻겠냐 해서 찾아서 한 거죠. (Kim, 25세, MTB 대학생 선수)

김효일에게 $\mathrm{MTB}$ 는 대학 진학에 동기를 부여하는 스 포츠 종목이었다. 그에게 있어 MTB는 '나를 대학에 보내 줄 스포츠'였던 것이다. 그러므로 취미로 MTB를 시작한 다른 연구 참여자들(강민우, 최범수, 한승민)과 달리 김 효일이 MTB에 오른 것은 대학 진학을 위해 철저히 계산 된 전략적 행위로 볼 수 있다. MTB 학생선수가 진학할 수 있는 대학이 많은 것은 아니지만, 국가대표 경험이 있 거나 선수 경력이 우수한 경우에는 지원할 수 있는 대학 이 더 많아진다. 특히 대학 진학보다 고교 출신 실업팀 선 수의 비율이 증가하고 있는 실태를 고려할 때 김효일의 동기는 더욱 유효해 보인다. 고등부에 등록된 MTB 선수 중에서 우수한 실력을 보유한 학생선수가 실업팀으로 진 출할 가능성이 크기 때문이다. 따라서 김효일의 경우처럼 대학 진학을 위해 MTB에 입문한 것은 MTB라는 스포츠 종목의 한국적 특수성을 이용한 사례로 볼 수 있다.

\section{"오로지 대학 입시를 위한 MTB 선수 생활"}

김효일은 대학 진학을 위해 MTB를 전략적으로 선택 한 만큼 고등학생 시절의 모든 훈련이 대학 진학에 맞춰 져있었다. 김효일의 훈련은 대학 진학에 유리한 대회에 서 입상하는 데에 집중되었다. 김효일은 전문적인 훈련을 받기 위해 개인 코치를 섭외해 훈련하며 대회를 준비했 다.

아카데미라고 하기에도 규모가 작은 $\cdots$. 산악자전거를 좋아 하시는 분이 제자를 받은 거죠. [중략] 아버지 지인의 추천으 로 [코치를] 알게 된 거죠. (Kim, 25세, MTB 대학생 선수)

학교 다닐 때는 고2 때까지만 해도 수업 다 들었어요. 수업 다 듣고 야자 같은 걸 안 하고 애들 학원 다니듯이 나와서 훈련하고. 근데 이제 이렇게 하다 보니깐 학교 끝나면 4시, 5 시 되잖아요. 날이 금방 저무니깐 어두워지잖아요. 자전거 를 타기[MTB]가 애매해져서 고3 때부터는 거의 1,2교시만
듣고 가서 훈련하고... 학교에서 많이 도와줬죠. (Kim, 25세, MTB 대학생 선수)

김효일은 MTB에 대한 전문 지식이 없었기에 훈련이 유난히 힘들었던 것으로 기억했다. 특히, 그는 체력적인 측면에서 상당한 에너지가 요구되는 $\mathrm{MTB}$ 의 특성을 잘 몰 랐던 탓에 선수 생활을 하면서 겪게 될 훈련의 강도를 전 혀 예상하지 못했었다. 하지만 대학 진학을 위해 시작한 만큼 끝을 봐야겠다는 생각으로 견뎌 낸 것으로 이야기하 였다.

축구 이런 거랑은 다르게 이게[MTB] 마라톤이더라고요. 자 전거로 하는 마라톤! 저는 몰랐죠, 처음에. 그냥 '위험한 스포 츠다 정도만 알았지, 마라톤처럼 힘든 건 몰랐죠. 하다 보니 깐 알았죠. 그만두고 싶다는 생각은 한 번도 안 했어요. (Kim, 25세, MTB 대학생 선수)

고등학교 2학년, 훈련 과정을 잘 견뎌낸 김효일은 고 등학교 3학년이 되면서 훈련의 성과가 나오기 시작했다. 고3 때는 지역 대표로 선발되었고, 국가대표 상비군으로 선발되어 여름 훈련에 참가하기도 했다. 그러나 그는 고 교생 MTB 학생선수 가운데 최상위권은 아니었기에 원 하는 대학에 진학하는 것이 불확실한 상태였다. 그러나 김효일은 대학에 합격하면서 MTB로 자신이 목표했던 것 을 달성할 수 있었다.

\section{"대학 입학과 동시에 자전거에서 내려버린 MTB 학생선수"}

김효일에게 있어 MTB는 대학에 가기 위한 전략적 도 구였다. 그의 전략은 유효했고 마침내 체육특기자 전형 으로 원하던 대학에 입학하게 되었다. 대학을 위해 MTB 에 올랐던 김효일은 대학 입학과 동시에 자전거에서 내 려버렸다. MTB를 통해 목표했던 것을 달성하자마자 더 이상 $\mathrm{MTB}$ 를 타지 않은 것이다. 김효일은 $\mathrm{MTB}$ 를 좋아한 적이 없었다. 그의 말대로 대학 진학을 위해 MTB를 선 택한 것이었다. 이런 이유에서 김효일은 대학 입학 후 더 이상 $\mathrm{MTB}$ 를 탈 이유가 없었다. 그 결과, 김효일의 대학 생활은 MTB 학생선수보다 대학생으로서의 비중이 더 큰 것으로 나타났다.

[대학] 합격 발표 나고 학교 다니면서 저는 진짜 학교대학 진 핵를 위해서 탄 거라서 학교 가서도 내가 막 프로 선수처럼 이 렇게 해야겠다는 마음이 없었어요. 그냥 일반 학생처럼 다니고 
싶었는데 학교에서는 원하는 게 그게 아니더라고요. 선수를 뽑은 거니깐 선수처럼 해라고 했는데 그냥 일반 학생처럼 다 녔어요. 좀 말을 안 들었죠. (KMm, 25세, MIB 대학생 선수)

김효일에 따르면 고등학교 3학년 전국체전대회 이후 사실상 $\mathrm{MTB}$ 에서 내렸던 것을 알 수 있다. 김효일이 지원 한 대학에서는 전국체전대회 이전까지의 수상 실적만 반 영했기에 전국체전 이후의 경기는 대학 입시에서 무의미 했다.

저는 마음속으로는 이미 [고3] 전국체전 끝나고 내려놨죠. 전 국체전 진짜 열심히 준비했거든요, 진짜 힘들었었는데. '이게 내 자전거 인생 마지막이니깐 조금만 참자'라는 식으로. 체전 후에 시합 하나 더 나갔던 거로 기억하는데 그냥 그땐 마음 이 없었죠. (Kim, 25세, MTB 대학생 선수)

김효일은 전국체전대회를 마지막으로 MTB 선수 생활 을 그만둔 것으로 언급했다. MTB를 타야할 이유가 사라 진 그는, 대학 진학 후 $\mathrm{MTB}$ 선수로 활동하지 않으며 대 학 생활을 보냈다. 결국, 김효일은 MTB 학생선수로 대학 에 입학했지만, MTB는 타지 않은 선수 아닌 선수였다. 그는 체육특기자로 대학에 진학했지만 그의 대학 생활에 서 자전거는 없었다. 물론, 대학의 요구에 따라 대회에 출 전하기도 했으나 이를 위해 체력단련을 한다거나 훈련을 하지는 않았다.

$\mathrm{MTB}$ 에서 내려온 김효일의 진로는 아직 정해지지 않 았다. 확실한 건 다시 MTB 선수 활동을 이어간다거나 자 전거와 관련된 일은 계획하고 있지 않다는 것이다. 그리 고 자신의 전공인 체육과 관련된 일도 계획에 없는 것으 로 이야기하였다. 현재 김효일이 생각하고 있는 진로는 펜 션 운영이었다. 가족 명의의 펜션을 자신이 운영하고 관 리하면서 진로에 대해 더 고민해 보겠다는 것이었다. 정리
하면, 김효일은 MTB 학생선수지만 선수 생활은 하지 않 은 채 대학 생활을 보낸 독특한 사례로 볼 수 있다. 그의 졸업 후 진로 역시 자전거와 무관했으며 전공인 체육과 도 거리를 두는 모습을 보였다. 김효일에게 MTB는 대학 진학을 위한 수단으로 활용된 측면이 컸고 그의 향후 진 로 탐색에서 있어서도 MTB는 찾아볼 수 없었다.

\section{논 의}

본 연구에서는 MTB 학생선수로 살아온 대학생 4 명의 이야기를 통해 이들이 MTB에 입문하게 된 배경과 동기 는 무엇인지, 학생선수로서 훈련과 목표는 무엇인지, 대 학생 생활과 향후 진로 탐색은 어떻게 이루어지는지 등을 내러티브 탐구로 살펴보았다. 연구에 참여한 4명의 MTB 학생선수들은 대학팀 소속으로 학생이자 운동선수라는 다중역할을 경험하고 있었고 그 속에서 자기만의 내러티 브를 만들어가고 있었다. 이들의 내러티브에서 도출된 결 과를 요약 및 논의하면 다음과 같다〈Fig. 1〉.

첫째, MTB 대학생 선수의 입문 배경과 동기는 각기 달랐다. 그렇지만 주로 취미로 시작해 학생선수의 단계 까지 이어지는 양상을 보였다. MTB 학생선수들은 취미 로 시작한 자전거에 재능을 보여 학생선수가 되는 경로 를 거쳤다. 이 과정에서 MTB에 대한 재능을 발견하는 주 체는 자기 자신인 경우도 있었고 가족이나 주변인에 의해 발견되기도 하였다. 이를 계기로 학생선수로 입문하게 되 고 대학(팀) 진학이나 실업팀 진출을 꿈꾸며 MTB를 타 게 된다. 본 연구에 참여한 MTB 학생선수들은 모두 대학 에 진학하였지만, 실업팀으로부터 영입 제안을 받거나 실 업팀 진출을 꿈꿨던 학생선수도 있었다. 결국, MTB 대학

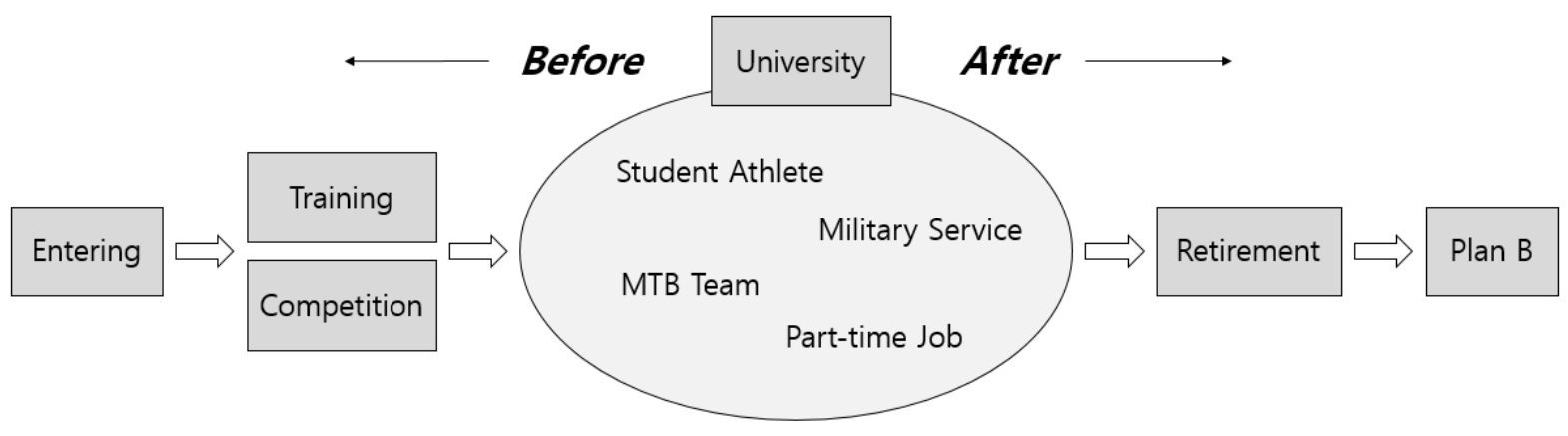

Fig. 1. Career model of MTB student athletes 
생 선수의 입문 배경과 동기는 모두 달랐지만 취미로 시 작한 운동이 학생선수의 길로 접어들게 하는 경로를 구축 하고 있었다.

흥미로운 사례는 연구 참여자 중 한 명이 대학에 진학 하기 위해 MTB를 시작한 것이었다. 이 사례는 체육특기 자 전형이라는 입시 제도를 염두에 둔 전략적 선택으로 분 석할 수 있다. 이 사례는 운동만으로 대학에 진학한다는 것이 전혀 불가능한 일이 아니라는 것을 보여준다. 이에 해당하는 학생선수는 고등학교 2학년 때 MTB를 시작했 지만, 그가 목표한 대로 대학에 진학할 수 있었다. 따라서 MTB 학생선수 중에는 취미로 시작해 학생선수가 된 사 례도 있었지만, 대학 진학을 위해 MTB를 타게 된 경우도 존재하는 것을 확인할 수 있었다. 이처럼 MTB 대학생 선 수들의 입문 배경과 동기는 각기 다른 면모를 지니고 있 었다. 본 연구에서는 이들의 내러티브를 통해 유사하면서 도 다른 경로의 MTB 입문 배경을 살펴볼 수 있었다.

그리고 연구에 참여한 대학생 선수들은 '자전거에 오 른' 동기는 달랐지만, 비인기 종목의 학생선수라는 점에 서 유사한 경험을 했음에 주목할만하다. 이들은 MTB 대 학생 선수로서 서로 다른 배경에서 성장했지만 MTB라 는 종목의 특수성으로 인하여 입문과 훈련, 나아가 대학 진학 및 향후 진로 설정에 있어 비슷한 고민을 하는 모습 을 보였다. 이에 따라 MTB 대학생 선수의 삶과 진로가 실 업팀 진출 외에는 자기 적성을 살려 직업을 갖기 어려운 상황이기에 MTB 대학생 선수들은 '플랜 B'를 준비하는 현실적인 모습을 보였다.

둘째, MTB 학생선수의 훈련과 목표는 대학 진학 또는 실업팀 진출에 맞춰져 있었다. 앞서 분석한 '입문의 배경 과 동기'에서 언급된 것처럼, MTB 학생선수의 목표는 상 급학교로의 진학이나 실업팀 선수가 되는 것이었다. 이러 한 목표는 MTB 학생선수의 꿈이 얼마나 획일적인지를 잘 보여준다. 이 연구에 참여한 MTB 학생선수들 역시 대 학 진학과 실업팀 진출이라는 목표에만 전념한 모습을 확 인할 수 있다. 특히, 이 연구에 참여한 MTB 학생선수들 의 내러티브에서는 대학 진학에 더 초점을 맞춘 것이 드 러났다. 이들은 MTB 학생선수로 대학에 진학하고자 대 회에 출전하고 입상하며 선수 경력을 쌓았다.

이들의 훈련 조력자는 개인 코치였다. 고교 MTB팀에 소속되지 않았던 학생선수들은 개인 코치를 섭외해 지도 받았던 것으로 드러났다. 팀에 소속되지 않은 MTB 학생 선수들에게 코치의 존재는 아주 특별했다. 체계적인 훈련
을 위한 조력자의 존재는 학생선수의 기량 강화에 긍정 적인 영향을 미친다(Coakley \& Pike, 2009). 결국, 이 연 구에 참여한 대학생 선수들은 자신을 지도해 줄 코치를 직접 섭외하여 훈련에 임했다. 이들은 코치에게 매달 일 정 금액의 수업료를 지급하며 훈련을 이어갔다. 개인 코 치의 섭외는 팀에 소속되지 않은 학생선수에게 꼭 필요한 존재로서 자신의 훈련을 도와줄 수 있는 든든한 조력자인 것이다. 그러나 코치에 대한 학생선수의 전적인 의존과 절 대적인 영향력으로 인해 마찰이나 갈등을 겪게 되는 일도 있었다. 이 같은 문제는 소속팀이 없는 학생선수들이 경험 하는 대표적인 문제로 대학 입시를 준비하는 MTB 학생 선수들이 공통적으로 경험하는 학원 스포츠의 단면으로 볼 수 있을 것이다. 그러므로 MTB 학생선수들의 훈련에 서 코치의 존재는 중요하면서도 세부적인 역할 및 관계 설정에 있어서는 특별한 주의가 요구된다.

또한, MTB 학생선수의 훈련과 목표가 상급학교 진학 또는 실업팀 진출에만 매몰되어 있는 것에 주의해야 할 것 이다. MTB 학생선수는 대학 또는 실업팀이라는 목표를 달성하기 위해 학업을 일부 포기하면서까지 훈련에 매진 하고 있다. 이러한 양상은 엘리트스포츠의 전형적인 폐해 로 지목되는 사안이다. 본 연구에 참여한 MTB 학생선수 들 역시 엘리트스포츠에서 나타나는 과몰입 훈련의 폐해 를 그대로 답습하고 있었다. 이로 인해 고교 시절 학교 수 업에 소홀했다거나 교육과정 중 일부를 생략한 경험들이 빈번히 확인되었다. 따라서 '공부하는 학생선수'가 아닌 '운 동하는 학생선수'의 잘못된 양상을 그대로 드러내는 문제 점에서 자유롭지 못했다. 예를 들어, 일주일에 두 번씩 조 퇴한다거나 소풍이나 수학여행 등과 같은 체험학습에 참 여하지 않은 것들은 학생선수로서 포기해야 하는 것이었 다. 그러므로 MTB 학생선수의 훈련과 목표로 인해 학습 권을 침해받는 일이 반복되지 않도록 해야 할 것이다.

셋째, MTB 대학생 선수의 대학 생활과 진로는 뜻밖의 양상으로 전개되었다. 대학에 진학한 MTB 학생선수들은 자신이 입학한 대학의 운동 환경에 불만족했다. 이들이 진 학한 대학의 MTB팀, MTB부는 코치와 감독이 부재하였 고 체계적인 선수 관리가 이루어지고 있지 않았다. 이로 인해 MTB 학생선수들은 상호 의존하거나 개인 훈련으로 선수 생활을 이어가는 양상을 보였다. 그 결과, 학생선수 의 기량이 대학 입학 전보다 더 떨어지는 모습을 보였다. 실제로 연구 참여자들은 대학생 선수에 대한 지원이 체계 적이지 않은 대학에 대한 강한 불만을 품고 있었으며 이 
러한 문제를 해결하기 위한 실질적인 개선 작업이 이루어 져야 한다고 주장하였다. 그럼에도 불구하고 연구에 참여 한 학생선수들이 소속된 대학에서는 MTB 학생선수를 위 한 학사제도 개편이나 지원책 마련 등에 있어 소극적인 모 습을 보였다. 체육특기자 전형으로 선발된 학생선수들에 대한 개입을 최소화하여 그들의 대학 생활을 다채롭게 하 였으나 운동에 전념하고자 했던 학생선수들의 기대에는 부응하지 못하는 면모를 보인 것이다. 따라서 대학생 선수 에 대한 체계적인 관리와 지원이 결여된 상황에서 운영되 는 대학 MTB팀 혹은 MTB부의 경우에는 소속된 학생 선수의 기량이 발전되지 않고 나아가 선수로서의 방향성 을 상실하게 되는 상황이 전개되고 있었다(Stambulova et al., 2009).

대표적인 예가 바로 MTB 학생선수의 진로 탐색에서 드러난다. 연구에 참여한 MTB 학생선수들이 이야기한 졸 업 후 계획에는 MTB 선수가 없었다. MTB 대학생 선수 의 미래에 MTB 선수가 없는 것이다. 이들이 말한 졸업 후 희망 진로는 '파일럿', 'BMX 지도자', '자전거 전문매장 운영자', '펜션 관리인' 등이었다. 이처럼 MTB 학생선수 가 꿈꾸는 미래는 MTB 선수와 무관한 직업이었다. MTB 대학생 선수들은 MTB 선수의 미래가 매우 불안정한 것 으로 여겼다. 이 같은 인식의 영향으로 MTB 대학생 선 수들은 향후 직업 선택에 있어 $\mathrm{MTB}$ 와 관련된 직업이 아 닌 '플랜 B'에서 자신의 진로를 구상하는 경우가 많았다. 이는 MTB 학생선수로 진출할 수 있는 직업의 폭이 좁다 는 것을 의미하는 한편 MTB 학생선수가 자신의 특기를 살려 진로 탐색을 할 수 있도록 하는 맞춤형 진로 교육의 도입이 시급하다는 것을 의미하기도 한다.

\section{결론 및 제언}

본 연구에서는 지금까지 주목하지 않았던 MTB 대학 생 선수의 내러티브를 심층적으로 살펴본 점에서 의의가 있으며, 그들의 내러티브를 이야기하고 다시 이야기한 점 에서 현실성이 가미된 연구로서 의미를 지닐 것이다. 무 엇보다 본 연구는 베일에 가려진 MTB 대학생 선수의 삶 과 진로를 내러티브로 살펴본 점에서 선행연구와의 차별 성을 가진다. 그리고 이 연구는 MTB 학생선수뿐만 아니 라 오늘날 학생선수들의 삶과 진로의 단면을 여과 없이 보여주고 있다는 점에서 한국 학원 스포츠가 당면한 학
생선수 지원 및 관리의 중요성, 진로 교육의 필요성 등을 상기시킨다. 그러므로 본 연구는 한국에서 비인기 종목 의 학생선수로 살아가는 것에 대한 현실을 MTB 학생선 수들의 이야기를 통해 그려낸 연구로서 시사하는 바가 클 것이다.

그러나 본 연구는 대학생 선수의 삶과 진로를 그려냄 에 있어 상대적으로 소외된 '개인'을 중심으로 그들의 자 기 역사에 무게를 둔 제한점이 있다. 향후 이어질 연구에 서는 소속팀의 체계적인 관리와 지원을 받는 학생선수들 의 사례를 살펴보는 것도 필요할 것으로 본다. 본 연구에 참여한 학생선수들은 중·고교 시절 학교운동부에 소속되 어 운동한 경험을 갖고 있지 않았다. 그리고 대학 진학 후 에도 체계적인 관리와 지원이 이루어지지 않았던 사례가 대부분이었으므로 이에 대비되는 사례에 대한 고찰도 필 요할 것이다.

후속연구에서는 MTB 학생선수들이 소속된 팀 문화를 살펴보거나 우수한 성적을 내고 있는 학생선수의 진로에 관해 탐구한다면 보다 확장된 논의를 전개할 수 있을 것 으로 생각한다. 즉, MTB 대학생 선수의 삶과 진로에 관 한 연구의 지평을 넓혀갈 수 있는 학술적 접근이 활발히 시도된다면 학생선수들이 겪는 부정적 경험에 대한 보완 이 이루어질 기회를 마련할 수 있을 것으로 본다. MTB 학 생선수에게 '자전거'는 단순한 이동수단이나 취미생활을 위한 것이 아니라 삶의 전부로 여겨질 만큼 중요한 것이 다. 비록 MTB 대학생 선수의 삶을 하나의 이야기로 풀어 내는 것은 불가능하지만 그들의 삶을 다채롭게 풀어낼 수 있는 심층 연구가 이어지길 기대한다.

\section{참고문헌}

Aitken, J. L. (1994). Becoming a teacher: Five questions in search of an answer. British Journal of In-service Education, 20(3), 345-357.

An, G. (2004). The Career Success Attitude for University Handball player, basket ball Players and student of majored physical education. Korean Journal of Physical Eduaction, 43(5), 615-624.

Bae, J. (2017). A study on the training experience and meaning of middle \& young-old aged men doing yoga: The men who do yoga against gender performance. Korean Journal of Sport Science, 28(1), 60-80. 
Bae, J., \& Choi, Y. (2016). Why Do We Play Basketball?: Narrative Inquiry for the Founding of 'A' Women's Basketball Club. Journal of Sport and Leisure Studies, 63, 417 431.

Cha, E. (2012). An Analysis on the Status of Occupation of DropOut Student Athletics. The Korea Journal of Sports Science, 21(5), 513-526.

Cheon, S., Lee, S., Park, K., Moon, H., Kim, J., \& Kim, M. (2015). Relationships between Career Stress and Morale of College Student Athletes as per Leadership Type of Coach. Journal of Coaching Development, 17(3), 27-36.

Choi, M. (2014). The Structure of Sport Drop-Out Motivation. Korean Journal of Sport Science, 25(4), 880-889.

Clandinin, D. J., \& Connelly, F. M. (1991). Narrative inquiry: Storied experience. Forms of Curriculum Inquiry, 121-154. CA: Sage Publications.

Coakley, J. (2011). Youth sports: What counts as "positive development?" Journal of Sport and Social Issues, 35(3), 306-324.

Coakley, J. J., \& Pike, E. (2009). Sport in society: Issues and controversies. North Ryde: McGraw-Hill.

Connelly, F. M., \& Clandinin, D. J. (2000). Narrative understandings of teacher knowledge. Journal of Curriculum and Supervision Summer, 15(4), 315-331.

Ham, H., Won, Y., \& Im, S. (2016). People who live with two wheels: MTB's life who changed their jobs through their leisure. The Korean Journal of Physical Education, 55(2), 95-110.

Han, I., Choi, S., \& Kang, B. (2009). A Study on Stress Factors of Junior High High School Ssireum Players. The Yongin University Journal of Martial Arts Institute, 20(1), 121-129.

Han, S. (2014). The Alienation of Student-athletes from Marx's Perspective. The Korean Journal of Physical Education, 53(2), 79-91

Han, U., Lim, J., \& Lee, C. (2017). Effect on recreation specialization of leisure flow for MTB participants. Journal of Leisure and Recreation Studies, 41(1), 45-55.

Hong, S. (2002), Effects of Sports Experience in the Youth on Leisure Attitude in Later. Journal of Sport and Leisure Studies, 18, 471-479.

Huberman, M. (1995). Working with life-history narratives, In H. McEwan, K. Egan (Eds.) Narrative in Teaching, Learning and Research. New York: Teachers College Press.

Huh, Y., \& Shon, J. (2016). Effects on Grade Management when Coaches Encourage Collegiate Athletes to Actively Participate in Class. Journal of coaching development, 18(2), 35-43.

Huybers-Withers, S. M., \& Livingston, L. A. (2010). Mountain biking is for men: Consumption practices and identity portrayed by a niche magazine. Sport in Society, 13(7-8), 12041222.

Hwang, Y., Lim, S., \& Yim, Y. (2014). A Study for Learning Network of University Student Athlete. Korean Journal of Sport Pedagogy, 21(2), 121-140.

Jang, J. (2010). Research on the Reasons for the Early Retirement of College Soccer Players and Change into Honor Students From Soccer Players. Journal of Korean Society for the Study of Physical Education, 15(3), 19-33.

Jang, K., Lee, D., Kim, W., \& Kim, J. (2013). The Influence of University Shooting Athletes Life Stress on Performance Impact. Sport Science, 31(1), 91-97.

Jin, H. (2011). The Study of Health Promotion Related Life Styles on University Athletes and physical Education Students. Journal of Korean Physical Education Association for Girls and Women, 25(4), 149-163.

Jung, J. (2014). Roles and Tasks of Kinesiology Faculty for Future Physical Education. Journal of Korean Society for the Study of Physical Education, 18(4), 15-28.

Kang, D., \& Kang, Y. (2012). The Experience Process of the Student-athletes Existing in the Changing Exercise-culture. The Korean Journal of Physical Education, 51(3), 63-77.

Kang, S. (2015). A Study on Differences of Career Barriers, Employment Stress, and Career Development Behavior among Collegiate athletes, Sport-majored College Students, and Non-sport-majored College Students. Korean Journal of Physical Education, 54(1), 83-95.

Kim, D. (2011). The process of adjustment to the school lives from a normal student to a student athlete. Korean Journal of Sport Pedagogy, 18(1), 71-90.

Kim, D., Kim. S., \& Kim, D. (2014). A Narrative Inquiry on the University Experiences of Student-Athletes to Study. The Korean Journal of Physical Education, 53(3), 329-340

Kim, E., Lee, K., \& Jang, S. (2015). 'Female Basketball Athletes Entered the College of Education': A Story about Education and Career of Student Athletes. Korean Journal of Physical Education, 54(4), 139-155.

Kim, J., \& An, G. (2017). Problems and Improvement Measures of the Drop-Out of College Taekwondo Kyorugi Players. Korea Society for Martial Arts: Journal of Martial Art, 11(3), 109-126.

Kim, J., \& Hong, M. (2017). Analyze in Importance and Expenditures by Parents of School Athletes. Journal of Korean Physical Education Association for Girls and Women, 31(3), 
59-71.

Kim, J. H. (2016). Understanding Narrative Inquiry: The Crafting and Analysis of Stories as Research. SAGE Publication. Kindle Edition.

Kim, H., \& Kwon, S. (2013). Exploring the meanings of injury experiences among college soccer players. Korean Journal of Sociology of Sport, 26(1), 107-124.

Kim, M., Choi, J., Kim, M., \& Lee, S. (2017). An Analysis of American Student-Athletes' Cognition of School Education. Journal of Sport and Leisure Studies, 70, 447-456.

Kim, S. (2015). Influence of Exercise Flow on Exercise Addiction in Mountain Bike Participant's. The Korea Journal of Sport, 13(2), 165-176.

Kim, Y. (2000). The Comparative Study on Social Network of University's Sports Players and Common Students. Journal of Sport and Leisure Studies, 13, 137-143.

Kim, Y. (2013). Qualitative research methodology II: Methods. Gyeonggi: Academy press.

Kim, Y. \& Lee, H. (2017). Qualitative Research: 15 Approaches. Gyeonggi: Academy press.

Lee, C., \& Chung, Y. (2017). The Narrative Inquiry on Studentathletes and Retired-athletes' Experiences. The Korean Journal of Physical Education, 56(1), 275-286.

Lee, D. (2015). The Study on Exercise Stress and Stress Release of Elite University Shooting Athletes. Sport Science, 32(2), 99-106.

Lee, H. (2011). The Experience Process of the Student-athletes who Perform both Study and Sport: Redefining Self. Korean Journal of Sociology of Sport, 24(1), 1-24.

Lee, H,. Son, N,. Lee, T., \& Lee, J. (2014). Student Athletes' Academic Advice and Friendship Network: Social Network Analysis. Journal of Learner-Centered Curriculum and Instruction, 14(6), 321-340.

Lee, K. (2013). A Study on the Intercollegiate Athletes' Perceptions toward Future Career Development. The Journal of Korea Society for Wellness, 8(1), 71-80.

Lee, K., Lim, T., \& Lim, S. (2016). Status-quo of Academic Supports, Barriers, and Improvement Suggestions from the Athletic Department Head's Standpoint. Journal of Korean Society of Sport Policy, 14(2), 107-123.

Lee, T., \& Ahn, Y. (2014). Directions for lives of student Athletes in University. Sports Science, 31(2), 111-122.

Lim, B., \& Park, J. (1997). Familism and Korean Female College Athletes. Journal of Korean Sociology of Sport, 8, 103-114.

Lim, E., Kim, J., Park, D., Lim, H., \& Jung, H. (2016). Narrative
Inquiries of Young Workers: Work, Learning, and Life of Vocational High School Graduates. Sejong-si: Korea Research Institute for Vocational Education \& Training.

Lim, J., Oh, Y., \& Yang, C. (2016). Effects of University Student Players' Achievement Goal Orientations on Career Maturity and Career Exploratory Behaviors. The Korean Journal of Sport, 14(3), 55-65.

Lim, Y. (2008) Narrative Inquiry of High School Teachers on Career Education. Journal of Vocational Education \& Training, 11(3), 193-218.

Park, C. (2013). Employment paths of female collegiate athletes. Journal of Learner-Centered Curriculum and Instruction, 13(5), 481-500.

Park, S., Jang, S., \& Hong, S. (2017) Exploring Student Athletes' Process of within Career Transition: Focused on Freshman Male Judo Athletes. The Journal of Korea Society for Wellness, 12(3), 333-349.

Park, S., \& Shin, S. (2017). Grounded Theoric Approach about Formation Process of Social Networks among Student Athletes who Dropped Out in University. The Korean Journal of Physical Education, 56(6), 95-115.

Park, H. (2016). A Study on the Change of University Student Athletes for the New Training Program: Focus on the Theory of Planned Behavior. Journal of Sport and Leisure Studies, 64, 677-689.

Park, K., \& Kang, H. (2017). An Analysis of Structural Relationships of Leisure Flow on Leisure Competence, Leisure Satisfaction by Participation Experience of the MTB Participants. The Korea Journal of Sports Science, 26(1), 313-325.

Park, J., \& Shin, J. (2017). The Development of Positive Psychological Intervention Through Single Case Design for University Student Athlete Using Single Case Design. The Journal of Korea Society for Wellness, 12(3), 413-422.

Park, M. (2007). A Narrative Inquiry into Elementary Teachers' Implementation of Integrated Curriculum: Based on Three Teachers' Stories. The Journal of Curriculum Studies, 25(1), 69-93.

Pflum, H. N., Nadler, D. P., \& Miller, M. T. (2017). Community College Student Athletes: Regular Students or ProAthletes in Training. College Student Journal, 51(4), 531-538.

Polkinghorne, D. E. (1988). Narrative knowing and the buman sciences. Albany: State University of New York Press.

Raabe, J., Readdy, T., \& Zakrajsek, R. A. (2017). Pathos and Orchestration in Elite Sport: The Experiences of NCAA DI Student-Athletes. The Sport Psychologist, 31(4), 344-355. 
Shin, Y. (2010). The infringement for the Learning rights which college student athletes recognize and the way for resolving them. Journal of Korean Society for the Study of Physical Education, 15(2), 161-177.

Son, S., Seo, H., \& Park, I. (2014). Relationship among Athletic performance, Self-management and Career Preparation Behaviors of Golf Majored Students. Journal of Korean Society for the Study of Physical Education, 19(1), 99-111.

Stambulova, N., Alfermann, D., Statler, T., \& CôTé, J. E. A. N. (2009). ISSP position stand: Career development and transitions of athletes. International Journal of Sport and Exercise Psychology, 7(4), 395-412.

Stebbins, R. A. (1982). Serious leisure: A conceptual statement. Pacific Sociological Review, 25(2), 251-272.

Yeom, J. (2003). Narrative inquiry in educational research: The concept, procedure, and dilemmas. Anthropology of Education,
6(1), 119-140.

Yi, J. (2011). The Sub-Culture and Schooling of College Student Athletes to Prepare for the Qualified Teacher Examination. The Journal of Yeolin Education, 19(3), 71 90.

Yoon, C., \& Lee, J. (2017). The Relationships among Achievement Goal-orientation, Sports Confidence, and Exercise Commitment in University Student-athletes. Journal of Digital Convergence, 15(11), 535-546.

Yoon, S,. Lim, J., \& Lee, C. (2012). Leisure Constrain for Male College Student-Athletes. Journal of Leisure \& Wellness, 2(1), 13-25.

Yu, T., \& Yi, J. (2004). Schooling and the culture of school athletics. Korean Journal of Physical Education, 43(4), 271-282.

Yim, Y., \& Ryu, T. (2014). A Qualitative Study of Undergraduate Student Athletes' Daily Life of Classroom. Korean Journal of Sport Pedagogy, 21(3), 113-140.

\title{
MTB 대학생 선수의 삶과 진로에 관한 내러티브 탐구
}

\author{
배재윤(연세대학교), 강현욱(단국대학교)
}

〔목적〕 본 연구의 목적은 MTB 학생선수의 대학 입학 전후의 삶을 총체적으로 들여다보고, 대학생 선수의 진로 탐색이 맥락적으로 어떻게 이루어지는지 살펴보는 데 있다. (방법) 이를 위해 MTB 대학생 선수 4명을 연구 참여자로 선정한 후, 이들의 삶과 진로를 내러티브 탐구의 방법으로 고찰하였다. 〔결과) MTB 대학생 선 수의 삶과 진로는 다음과 같이 재현 및 전개되었다. 첫째, MTB 대학생 선수가 MTB에 입문하게 된 배경에는 '자기 의지' 또는 '가족 및 주변인의 영향'으로 나타났고, 동기는 '취미 생활의 연장', '대학 진학' 등과 같이 구체 적인 이야기를 갖고 있었다. 둘째, MTB 학생선수의 훈련과 목표는 대학 진학이라는 '입시'에 맞춰져 있었고, 이를 위해 훈련하고 대회에 참가한 것으로 나타났다. 셋째, MTB 대학생 선수의 대학 생활은 '학생선수에 대한 관리 및 지원 체계'와 밀접한 관련이 있었고, 이들의 진로 탐색은 '선수로서 자신의 장래성'뿐만 아니라 'MTB 선수의 직업 전망' 등을 복합적으로 고려해 이루어졌다. MTB 대학생 선수들은 비인기 종목의 특성과 선수 생활에 대한 불투명한 미래를 이유로 자기만의 '플랜 B'를 준비하며 자연스레 은퇴를 준비하는 모습을 보였다. 〔결론〕 MTB 대학생 선수는 비인기스포츠의 좁은 무대에서 자기 삶과 진로에 대한 진지한 고민을 하고 있었 다. 이 같은 이야기를 바탕으로 MTB 대학생 선수의 삶과 진로에 대한 비판적 논의를 시도하고 나아가 오늘날 비인기 종목 학원 스포츠의 학생선수들을 위한 시사점을 제시하였다.

주요어: 산악자전거, 비인기스포츠, 엘리트스포츠, 학생선수, 대학생 선수, 진로, 내러티브 탐구 